\title{
COMPETITION OR CONTROL I: THE CHAOS IN THE CASES*
}

\author{
G. E. Hale $\dagger$ and Rosemary D. Hale $\frac{\ddagger}{\div}$
}

\section{Application of the Antitrust Laws to Public Utilities: Statement of the Problem}

At common law and under both state and federal statutes monopolization and restraint of trade are forbidden. The leading federal statute, the Sherman Act, ${ }^{1}$ has assumed virtually constitutional stature. Some state legislation ${ }^{2}$ is patterned closely after the federal statutes; other states have no statutes and still others have enacted measures of a different character. It is worth noting that the antitrust statutes of several states are specifically directed at various industries now subject to regulation. Thus there are enactments addressed to telegraph companies, gas companies, telephone companies, railroad companies, street railroads and the like. ${ }^{3}$ In general, both state and federa! legislation seek to enforce a policy of competition. Monopolies and monopolistic acts are anathemas.

For centuries, however, the common law has recognized certain "callings" as "affected with a public interest." Persons engaged in those "callings" are under a duty to serve all who apply for their products at reasonable prices. In return they may afford certain protection from the rigors of competition. ${ }^{4}$ Thus, Lord Blackstone noted that:

* This Article is the first of a series by the authors dealing with the application of antitrust laws to regulated industries. The present Article sets forth the decisions and points out the conflicts which exist. Subsequent articles will analyse the possible reasons for the differences in approach found in the cases with a view to presenting a coherent picture of the present state of the law. An attempt will then be made to suggest rational standards for the future.

$\dagger$ A.B., Yale College, 1935; LL.B., Harvard Law School, 1938; J.S.D., University of Chicago, 1940. Member, Illinois bar.

$¥$ A.B., Mount Holyoke College, 1940; M.A., American University, 1946. Lecturer in Economics, Lake Forest College.

The authors were assisted by Emily J. Niemet of the Illinois bar. The assistance of John A. Henry, Esq. in the gathering of materials is gratefully acknowledged.

1. 26 SrAT. 209 (1890), as amended, 15 U.S.C. \$\$ 1-3 (Supp. IV, 1957).

2. WPA, State ANri-Trust Laws (Martin ed. 1940).

3. Id. at LIv.

4. In dissenting from a substantive due process decision, the late Mr. Justice Brandeis said: "The cases just cited show that, while, ordinarily free competition in the common callings has been encouraged, the public welfare may at other times demand 
"If a ferry is erected on a river, so near another ancient ferry as to draw away its custom, it is a nuisance to the owner of the old one. For where there is a ferry by prescription, the owner is bound to keep it always in repair and readiness for the ease of all the king's subjects; otherwise he may be greviously amerced; it would be therefore extremely hard if a new ferry were suffered to share his profits, which does not also share his burthen." 5

And both the federal and state governments have intervened legislatively in a wide variety of industries with the result that for many, government fixes prices, licenses entry and controls the services rendered. In these sectors of the economy regulation and not competition is the order of the day. ${ }^{6}$

It has often been urged that the enactment of interventionist legislation of the type just described supersedes the antitrust laws. Writers ${ }^{7}$ and courts ${ }^{8}$ have stressed that regulation is to serve in lieu of competition and is to protect the business as well as the public. Regulation and competition are supposedly to be viewed as mutually exclusive regimes, the introduction of one to be followed by the disappearance of the other. Nevertheless, many courts have insisted on applying the antitrust laws to regulated industries unless barred by a statutory exemption for the type of conduct under judicial scrutiny. In reply, legislatures have sometimes seen fit to spell out specific exemptions. And in other instances courts themselves, particularly when dealing with politically powerful groups, have found such exemptions to exist by implication. ${ }^{9}$

In the pages which follow, we set forth decisions involving the application of antitrust principles to a broad range of industries commonly regarded as regulated. We are not concerned with the validity

that monopolies be created. Upon this principle is based our whole modern practice of public utility regulation. It is no objection to the validity of the statute here assailed that it fosters monopoly. That, indeed, is its design. The certificate of public convenience and invention [sic] is a device-a recent social-economic invention-through which the monopoly is kept under effective control by vesting in a commission the power to terminate it whenever that course is required in the public interest." New State Ice Co. v. Liebmann, 285 U.S. 262, 304 (1932).

\section{3 BLACKSTONE, CoMmenTARIES *219.}

6. See Hardman, The Changing Law of Competition in Public Service, $33 \mathrm{~W}$. Va. L.Q. 219, 221 (1927). Cf. Parker v. Brown, 317 U.S. 341 (1943), in which it was held that the antitrust laws did not extend to activities of the states.

7. 3 Pond, Public Utilimies $\$ 901$ (4th ed. 1932). (1923).

8. See Choate v. Illinois Commerce Comm'n, 309 Ill. 248, 256, 141 N.E. 12, 15-16

9. See United States v. Hutcheson, 312 U.S. 219, 229-33 (1941) ; United States v. Maryland Cooperative Milk Producers, 145 F. Supp. 151, 154 (D.D.C. 1956); cf. Fosburgh v. California \& Hawaiian Sugar Co., 291 Fed. 29 (9th Cir. 1923); Hadley, Public Utilities and the Anti-Trust Law, 10 B.U.L. REv. 351, 359-62 (1930). 
of that regulation. ${ }^{10}$ Nor are we here concerned with the division of power between the nation and the states or between the state and its subdivisions; we take no account of decisions dealing with the scope of corporate franchises or with the validity of exclusive rights granted to corpoirations engaging in "public callings." 11 Our focus is upon the substantive application of the antitrust statutes and hence we do not consider their purely adjective aspects, such as the remedies available thereunder, nor do we go far into the interesting and important question of primary jurisdiction. ${ }^{12}$

We turn, then, to a survey of the several industries affected by state, federal and local regulation. As to each we have assembled cases illustrating application of antitrust statutes and principles thereto. While the categories in which the industries are grouped necessarily somewhat overlap, it is believed that problems of industry definition need not concern us in the present study.

\section{RAILROADS}

Governmental control over railroading, instituted many decades ago, is today the prototype of modern public utility regulation. In addition to federal intervention through the Interstate Commerce Act, ${ }^{13}$ most states have also enacted legislation subjecting the railroads to detailed supervision. ${ }^{14}$ Commissions commonly control entry, rates, service, abandonment of lines or branches, ${ }^{15}$ and even methods of

10. Thus we need take no account of the long line of decisions holding that interventionist statutes denied substantive due process of law. In any event those decisions, dealing with the constitutionality of state and federal legislation fixing prices and the like, merely held that the due process clauses of the constitutions did or did not guarantee such economic freedom.

11. Hadley, supra note 9 , at 353-55.

12. "Primary jurisdiction" is the adjective side of the conflict between competition and intervention. It is somewhat akin to the doctrine that one must exhaust his administrative remedies before seeking judicial relief. It requires, in brief, that a litigant resort to the administrative tribunal created by interventionist legislation before seeking to enforce the antitrust laws in court. Its origins lay in rate reparation cases wherein relief was held to be available before the Interstate Commerce Commission and not in the courts. Later it spread into other areas of regulation and now finds widespread application. Jaffe, Primary Jurisdiction Reconsidered: The Anti-Trust Lawes, 102 U. PA. L. REv. 577, 581-83 (1954). Compare Schwartz, Legal Restrictions on Competition in the Regulated Industries: An Abdication of Judicial Responsibility, 67 HARv. L. REv. 436 (1954), writh von Mehren, The Anti-Trust Lazes and Regulated Industries: The Doctrine of Primary Jurisdiction, 67 HARv. L. REv. 929 (1954). Perhaps it is also well to note that citation of cases herein is illustrative, rather than exhaustive.

13. 24 Stat. 379 (1887), as amended, 49 U.S.C. \$§ 1-10 (Supp. IV, 1957). It has been the subject of frequent amendment chronicled at length in 1 SHARFMaN, THE INTERSTATE COMMERCE CoMmission (1934). Later developments are summarized in Harbeson, The Transportation Act of 1940, 17 J. LAND \& P.U. Econ. 291 (1941).

14. See Ill. Ann. Stat. c. $1112 / 3$, \$\$ 1-10.5 (Smith-Hurd 1954).

15. 24 STar. 379 (1887), as amended, 49 U.S.C. § 1 (18) (1952). 
financing. ${ }^{16}$ Discrimination among shippers is prohibited ${ }^{17}$ and the federal statute contains a well-known clause forbidding the charging of a higher rate for a short haul than a long haul over the same route in the same direction. ${ }^{18}$ The Interstate Commerce Commission may approve pooling of earnings, division of traffic and mergers and consolidations of railroads. ${ }^{19}$

Even apart from statutory exemptions, it was early asserted that the extensive controls over railroads vested in regulatory agencies made inapposite application of the antitrust laws. The argument was first raised only seven years after passage of the Sherman Act in United States v. Trans-Missouri Freight Ass' $n,{ }^{20}$ which involved an agreement on rates. The Court, in rejecting this argument, ${ }^{21}$ found that the Interstate Commerce Act had not been repealed by implication but that the railroads were nevertheless subject to the Sherman Act. To the contention that if the Congress had intended to apply the Sherman Act to railroads it would have amended the Interstate Commerce Act directly, the Court replied that the Commerce Act did not authorize the kind of agreement before the Court ${ }^{22}$ nor did it make any pretense of being an inclusive "set of rules and regulations . . . to govern . . . in all cases." 23 It could find no reason why the kind of conduct proscribed by the Sherman Act would be any the less evil when indulged in by railroads than when indulged in by industrial corporations. ${ }^{24}$

Mr. Justice White joined with three of his colleagues in dissenting. He wrote that in the Sherman Act Congress did not intend to interfere with the control and regulation established by the Interstate Commerce Act nor to promote a constant fluctuation of the regulated rates through competition. To the contrary, he found that agreements among competing as well as connecting carriers seeking to prevent the undercutting of rates had existed prior to the enactment of the Interstate Commerce Act and were not only not forbidden by that legislation but were to be deemed instruments tending to secure its successful evolution. ${ }^{25}$

16. 24 STAT. 379 (1887), as amended, 49 U.S.C. \$ 1 (14) (1952).

17. 24 SтAт. 380 (1887), as amended, 49 U.S.C. $\$ 5$ (11) (1952).

18. 24 STAт. 380 (1887), as amended, 49 U.S.C. $\$ 4$ (1952).

19. 24 STAT. 380 (1887), as amended, 49 U.S.C. $\$ 5$ (1952).

20. 166 U.S. 290 (1897).

21. Id. at 314-17.

22. Id. at 314-15.

23. Id. at 316 .

24. Id. at $322-23,325$.

25. Id. at 364 . 
In view of the split in the Court, the railroads continued to press the argument. ${ }^{26}$ Although the Sherman Act was applied to railroads in a long series of decisions, ${ }^{27}$ the Supreme Court was told again in 1945 in Georgia v. Pennsylvania R.R. ${ }^{28}$ that regulation must imply exemption. Once more the Court, divided five to four, held that the antitrust laws could be applied to certain kinds of railroad conduct:

"These carriers are subject to the antitrust laws. . . Conspiracies among carriers to fix rates were included in the broad sweep of the Sherman Act. . . . Congress has not given the Commission . . . authority to remove rate-fixing combinations from the prohibitions contained in the antitrust laws. It has not placed these combinations under the control and supervision of the Commission. Nor has it empowered the Commission to proceed against such combinations and through cease and desist orders or otherwise to put an end to their activities. Regulated industries are not per se exempt from the Sherman Act. "29

Mr. Chief Justice Stone, joined by Justices Roberts, Frankfurter and Jackson, dissented. He urged that the plaintiff had failed to exhaust its administrative remedies under the Interstate Commerce Act; that the Interstate Commerce Commission had exclusive jurisdiction to determine the lawfulness of all rates appearing in filed tariffs and authority to suspend rates; and that the Commission had been directed to act in such a way as to foster the national transportation policy and to consider a multitude of factors. ${ }^{30} \mathrm{He}$ went on to point out that if one plaintiff were allowed relief under the antitrust laws the effect would be to prevent that uniform application of rates and service envisaged by the Interstate Commerce Act and to create discrimination against others. ${ }^{31}$

Although the law seems settled that railroads are not per se exempt from the antitrust laws, the courts have still not been willing to make available a complete arsenal of antitrust remedies against them.

26. See United States v. Joint Traffic Ass'n, 171 U.S. 505, 529 (1898); Northern Securities Co. v. United States, 193 U.S. 197, 343 (1904). In the latter case Mr. Justice White again dissented. Id. at 376 .

27. Terminal Warehouse Co. v. Pennsylvania R.R., 297 U.S. 500, 515-16 (1936);

United States v. Union Pac. R.R., 226 U.S. 61 (1912); United States v. Terminal R.R. Ass'n, 224 U.S. 383 (1912), contempt proceedings reported, 266 U.S. 17 (1924); United States v. Southern Pac. R.R., 259 U.S. 214 (1922), subsequent proceedings reported, 290 Fed. 443 (D. Utah 1923); Meeker v. Lehigh Valley R.R., 183 Fed. 548, 550-51 (2d Cir. 1910) ; United States v. Association of Am. R.R., 4 F.R.D. 510, 522, 524 (D. Neb. 1945) ; Tift v. Southern Ry., 138 Fed. 753 (C.C.W.D. Ga. 1905), aff'd, 148 Fed. 1021 (5th Cir. 1906), aff'd, 206 U.S. 428 (1907); United States v. Atchison, Topeka \& Santa Fe Ry., 142 Fed. 176, 184 (C.C.W.D. Mo. 1905).

28. 324 U.S. 439 (1945).

29. Id. at 456 .

30. Id. at 476-78.

31. Id. at 488. 
The question first arose in Keogh v. Chicago \& N.W.R.R. ${ }^{\mathbf{2}}$ Competing carriers were alleged to have fixed rates by agreement. The rates were then filed with the Interstate Commerce Commission, and the Commission approved them after a hearing. A shipper filed an action under the Sherman Act seeking to recover treble damages, alleging that the rates had been fixed by agreement, whereby he had been injured. The Court denied relief, holding that the injured shipper could not recover treble damages because Congress had intended him to recover only reparations under the provisions of the Interstate Commerce Act. The Court pointed out that if treble damages were allowed, the remedy would constitute a discrimination against other patrons of the railroad. In dictum, however, it added that approval of the rates by the Interstate Commerce Commission would not bar an action by the Attorney General. A few years later in Central Transfer Co. v. Terminal Ry. $A s s^{\prime} n, 33$ a private party brought suit to enjoin acts of railroad carriers allegedly in violation of the antitrust laws but also within the jurisdiction of the Interstate Commerce Commission. Again relief was denied; the Court declared that under the statute only the Attorney General could secure injunctive relief, pointing out that injunctive relief in favor of a private party would disrupt the Commission's regulatory pattern. ${ }^{34}$

There has been greater division of opinion in the state courts but the weight of authority appears to support the federal view that antitrust statutes may be applied to railroads. In a leading decision ${ }^{35}$

32. 260 U.S. 156 (1922). Cf. Texas \& Pac. Ry. v. Abilene Cotton Oil Co., 204 U.S. 426 (1907).

33. 288 U.S. 469 (1933).

34. Cf. Seatrain Lines v. Pennsylvania R.R., 207 F.2d 255, 260, 262 (3d Cir.), cert. denied, 345 U.S. 916 (1953); Wheeling \& L.E. Ry. v. Pittsburgh Ry., 33 F' 2d 390, 393 (6th Cir. 1929). See also Mclean Trucking Co. v. United States, 321 U.S. 67,83 (1944). Instructive, too, is the subsequent history of several of the cases in which the antitrust laws have been held applicable to railroads. In United States v. Terminal Ry. Ass'n, 224 U.S. 383 (1912), contempt proceedings were attempted by way of enforcement. 266 U.S. 17 (1924). The Court, however, held that the parties sought to be benefited by the prior judgment must proceed before the Interstate Commerce Commission, implying that the courts could not give effective relief without endangering the regulatory pattern. In United States v. Southern Pac. Co., 259 U.S. 214 (1922), the Court held that the Southern Pacific Company must divest itself of the Central Pacific Lines. Thereafter the Southern Pacific applied to the Interstate Commerce Commission and received permission to acquire the Central Pacific by means of a lease. It was held that then the decree in the antitrust case must recognize the validity of the acquisition approved by the Interstate Commerce Commission. 290 Fed. 443 (D. Utah 1923).

35. State v. Missouri, Kan. \& Tex. Ry., 99 Tex. 516, 91 S.W. 214 (1906). Accord, Pearsall v. Great No. Ry., 161 U.S. 646 (1896); Central R.R. v. Collins, 40 Ga. 582, 640 (1869); Evansville So. \& No. Ry. v. Evansville \& E. Elec. Ry., 50 Ind. App. 502, 98 N.E. 649 (1912); Chicago, I. \& L. Ry. v. Southern I. Ry., 38 Ind. App. 234, 70 N.E. 843 (1904); Eel River R.R. v. State, 155 Ind. 433, 455, 57 N.E. 388, 395, 396 (1900); Texas \& Pac. Ry. v. Southern Pac. Ry., 41 La. Ann. 970, 980, 6 So. 888, 891 (1889); Bennett v. Southern Ry., 211 N.C. 474, 483-86, 191 S.E. 240, 246, 248 (1937) ; Transportation Co. v. Ohio River Pipe Line Co., 22 W. Va. 600, 625 (1883). 
the Texas Supreme Court rejected the contention that a state law creating a railroad commission and investing it with power to regulate rates charged by railroad and express companies exempted combinations between them from the state antitrust laws. Other cases reach similar results by applying the common-law restraint of trade doctrine and in still others account is taken of specific constitutional or statutory directives to apply antitrust principles to railroads. ${ }^{36}$

A case looking in the opposite direction is Yazoo \& Miss. Valley $R y$. v. Searles. ${ }^{37}$ An association of railroads organized a boycott of the plaintiff in order to enforce rules with respect to payment for demurrage. As a result plaintiff's competitors received sidetrack service which he was denied. Suit was brought under a state antitrust statute and the defendants answered that the demurrage rules had been issued by the state railroad commission. The court accepted this as a defense, holding that concerted action to enforce the car service rules of the state railroad commission was not within the antitrust laws. It stressed the desirability of uniform charges for demurrage and pointed out that if the plaintiff were not required to pay such charges he would obtain an advantage over his rivals. ${ }^{38}$

To complete the railroad picture, note should be taken of the specific exemption from the federal antitrust laws afforded certain transactions by the Reed-Bulwinkle Act, an amendment to the Interstate Commerce Act. The railroads are authorized to enter into agreements with respect to rates, divisions, charges for equipment and the like and to submit the same to the Interstate Commerce Commission for approval. There follow several limitations, including clauses mak-

36. See, e.g., Ilu. Consr. art. 11, § 11; Chicago, M. \& St. P. Ry. v. Franzen, 287 Ill. 346, 122 N.E. 492 (1919); Illinois State Trust Co. v. St. Louis I. M. \& S. Ry., 208 IIl. 419, 70 N.E. 347 (1904) ; American Loan \& Trust Co. v. Minnesota \& N. W. R.R., 157 IIl. 641, 650-51, 42 N.E. 153, 156 (1895) ; Louisville \& N. Ry. v. Commonwealth, 97 Ky. 675, 31 S.W. 476 (1895), aff'd, 161 U.S. 677, 698 (1896); Pennsylvania R.R. v. Commonwealth, 7 Atl. 368 (Pa. 1886); Gulf C. \& S. F. Ry. v. State, 72 Tex. 404, 10 S.W. 81 (1888); WPA, STATE ANTI-Trust LAWS LII (Martin ed. 1940). In several additional decisions the courts have indicated that they thought antitrust statutes were applicable to railroads but did not specifically so hold. Lisman v. Knickerbocker Trust Co., 211 Fed. 413, 421 (6th Cir. 1914); Cleveland C. C. \& I. Ry. v. Closser, 126 Ind. 348, 26 N.E. 159 (1890) ; Venner v. New York Cent. \& H. R.R., 177 App. Div. 296, 305-07, 164 N.Y. Supp. 626, 632-33 (2d Dep't 1917), aff'd per curiam, 226 N.Y. 583, 123 N.E. 893, cert. deried, 249 U.S. 617 (1919); Paterson v. Southern Ry., 214 N.C. 38, 198 S.E. 364 (1938) ; Carolina Motor Serv. v. Atlantic Coast Line R.R., 210 N.C. 36-39, 185 S.E. 479,481 (1936); Cumberland V.R.R. v. Gettsyburg \& H. Ry., 177 Pa. 519, 35 At1. 952 (1896) ; State ex rel. Cascade R.R. v. Superior Court, 51 Wash. 346, 98 Pac. 739 (1909).

37. 85 Miss. 520, 37 So. 939 (1905).

38. Id. at 545-46, 37 So. at 948. See State ex rel. Thompson v. National Ry. \& Light, 151 Tenn. 77, 90-92, 268 S.W. 120, 124 (1925). Among other decisions looking in the same general direction are Manchester L. R.R. v. Concord Ry., 66 N.H. 100, 20 Atl. 383 (1890); Ives v. Smith, 3 N.Y. Supp. 645, 654 (Sup. Ct. 1888), aff'd per curiam, 55 Hun. 606 (N.Y. Sup. Ct. 1889). See also Morawetz, Prrvate CorporaTIONS $\S 1131$ (2d ed. 1886); H.R. REP. No. 1100, 80th Cong., 2d Sess. 25 (1947). 
ing it clear that there should be continued competition in rates between railroads and other carriers and that the Commission must find that each party to the agreement retains the free and unrestrained right to take independent action. Finally, if the agreement is approved by the Commission, the parties are relieved from the operation of the antitrust laws, subject to any terms and conditions prescribed by the Commission..$^{39}$ The Commission similarly has power to approve mergers. It has commented that the standard it uses to determine whether a proposed merger should be approved is different from that used by the Justice Department and other federal agencies in enforcing the antitrust laws. "This is necessarily so because a completely regulated industry is involved, which regulation in itself protects the public interest." 40

\section{GAS}

Manufacture and distribution of gas by means of fixed facilities for domestic, commercial and industrial purposes have long been the subject of regulation. ${ }^{41}$ Under state legislation administrative agencies possess sweeping controls over operation of gas companies. They are usually empowered to license entry into the field, fix rates, establish service standards, prescribe uniform systems of accounting, fix methods of depreciation, control the issuance of securities and permit mergers and consolidations. ${ }^{42}$ The role of the federal government has been relatively recent and somewhat limited. ${ }^{43}$ The federal statute is primarily aimed at the interstate transmission of the natural product and gives the Federal Power Commission authority to fix rates, to prohibit discrimination, to license firms entering the field, to compel extension of service and the like. ${ }^{44}$ It is worth noting that the Natural Gas Act contains the following provisions :

39. 36 STAT. 548 (1906), 49 U.S.C. $\$ 5$ b (9) (1952). It will, of course, be observed that the Reed-Bulwinkle amendment does not exempt the carriers from many other provisions of the federal antitrust laws.

40. Hearings Before the Subcommittee on the Study of Corporate Mergers by the Senate Committee on the Judiciary, 81st Cong., 2d Sess. 474 (1956). See 24 STAT. 384 (1887), 49 U.S.C. $\$ 15$ (1952).

41. E.g., Irl. ANN. Stat. c. $1112 / 3, \S 10.3$ (Smith-Hurd 1954). See also IrL. ANn. Stat. c. $32, \S \S 399-410$ (Smith-Hurd 1954), permitting consolidation of gas companies.

42. Barnes, The Economics of Public Utility Ragulation 212-13 (1942); Troxel, Economics of Public UTilitiss 76-77, 466 (1947).

43. Natural Gas Act, 52 Srar. 821-33 (1938), as amended, 15 U.S.C. $\$ \$ 717-17 \mathrm{w}$ (1948), as amended, 15 U.S.C. \& 717 (Supp. IV, 1957).

44. 52 STAT. 822 (1938), 15 U.S.C. $§ 717 \mathrm{c}$ (1952). Recently controversy has arisen with respect to the scope of the jurisdiction of the Federal Power Commission to fix the producers' price of natural gas. See Phillips Petroleum Co. v. Wisconsin, 347 U.S. 672 (1953). 
"Nothing contained in this section shall be construed as a limitation upon the power of the Commission to grant certificates of public convenience and necessity for service of an area already being served by another natural-gas company. ${ }^{45}$. . . . The Commission may transmit such evidence as may be available concerning such acts or practices or concerning apparent violations of the federal antitrust laws to the Attorney General who, in his discretion, may institute the necessary criminal proceedings." 48

A more even division of opinion has been recorded with respect to the application of antitrust principles to gas companies than in the case of railroads. Many of the early cases, relying on the common law and the duties of the gas companies under their charters and franchises, insist on competition and prohibit contracts for divisions of territory. Thus in Chicago Gas Light \& Coke Co. v. People's Gas Light $\mathcal{E}$ Coke Co., ${ }^{47}$ two companies authorized to lay mains in the city of Chicago had made an agreement dividing territory and selling each other property in the other's territory. Later one of them disregarded the agreement and began to compete. A bill for specific performance of the contract was denied, the court declaring that the contract for division of territory was unenforceable in equity because each company owed a public duty to serve the entire area. ${ }^{48}$ The contract was also denounced as tending to create a monopoly..$^{49}$

Two important decisions indicate that certain gas company activities should not be subject to antitrust statutes or the common-law rules against restraints of trade. Weld v. Gas \& Elec. Light Comm'rs ${ }^{50}$ involved a commission-approved agreement by two public utility companies to divide territory. The court held that a consumer could not complain of a division of territory on the ground that in this area the state had adopted a policy of regulation as a reliance against the

45. 56 STAT. 83 (1942), 15 U.S.C. § 717f (g) (1952).

46. 52 SrAT. 832 (1938), 15 U.S.C. \$ 717s (b) (1952).

47. 121 III. 530, 13 N.E. 169 (1887).

48. Id. at 540, 542, 13 N.E. 172, 173. Accord, Gibbs v. Consolidated Gas Co., 130 U.S. 396 (1889) ; People ex rel. Peabody v. Chicago Gas Trust Co., 130 IIl. 268, 22 N.E. 798 (1889); State $e x$ rel. Snyder v. Portland Natural Gas Co., 153 Ind. 483, 485, 53 N.E. 1089, 1091 (1899). See also McKinney v. Kansas Natural Gas Co., 206 Fed. 772 , 777 (D. Kan. 1913) ; People ex rel. Fitzhenry v. Union Gas Co., 254 IIl. 395, 98 N.E. 768 (1912) ; City of Vincennes v. Citizens' Gaslight Co., 132 Ind. 114, 118, 31 N.E. 573, 576 (1892) ; Citizens' Natural Gas Co. v. Town of Elwood, 114 Ind. $332,334,16$ N.E. 624, 626 (1888) ; Gathright v. Byllesby \& Co., $154 \mathrm{Ky} .106,157$ S.W. 45 (1913) ; City of Okmulgee v. Okmulgee Gas Co., 140 Okla. 88, 98-100, 282 Pac. 640, 649-51 (1929); Charleston Natural Gas Co. v. Kanawha Gas Co., 58 W. Va. 22, 50 S.E. 876 (1905); Parkersburg Gas Co. v. Parkersburg, 30 W. Va. 435, 4 S.E. 650 (1887); Lake, Connpetition in the Public Utility Fields, 10 MIss. L.J. 197, 199 (1938).

49. Chicago Gas Iight \& Coke Co. v. People's Gas Light \& Coke Co., 121 Ill. 530, 544,13 N.E. 169, 174 (1887).

50. 197 Mass. 556, 84 N.E. 101 (1908). 
evil effect of monopoly to the exclusion of competition. ${ }^{51}$ In Attorney Gen. v. Consolidated Gas Co.,52 the court held lawful a combination of competing gas companies. In sweeping language it declared it to be "the settled policy of the state to discourage competition" between two or more gas companies. ${ }^{53}$ eld and Consolidated cannot be reconciled with Chicago Gas, Light \& Coke Co. A conflict of cases in this industry is clear.

\section{WATER}

Water companies are, of course, commonly regulated. ${ }^{54}$ Relatively few cases have dealt with the gathering and supplying of water through permanent facilities. Such authority as there is indicates that water company activities are to be afforded exemptions from antitrust statutes, although at least one decision says that an exclusive franchise to operate a water system is invalid ${ }^{55}$ Other decisions suggest, if they do not so hold, that monopoly can be tolerated in the water business. ${ }^{56}$ Some of these cases are concerned merely with the constitutionality of statutes conferring an exclusive privilege to operate a waterworks and the like. In Oakes v. Cattaraugus Water Co., ${ }^{57}$ however, the court seemed to be conscious that it was dealing with a restraint of trade problem. Defendant water company entered into a contract with the plaintiff who agreed not to seek a franchise to operate a rival system and to aid the defendant in the construction of its waterworks and mains. Plaintiff performed his duties and sued defendant for nonpayment. Defendant pleaded the invalidity of the contract but the

51. Id. at 558, 84 N.E. at $102-03$.

52. 124 App. Div. 401, 108 N.Y. Supp. 823 (1st Dep't 1908).

53. Id. at 406, 108 N.Y. Supp. at 826. See Twin City Pipe Line Co. v. Harding Glass Co., 283 U.S. 353, 358 (1931) ; Empire Gas \& Fuel Co. v. Lone Star Gas Co., 289 Fed. 826, 832 (N.D. Tex. 1923) ; Rafferty v. Buffalo City Gas Co., 37 App. Div. 618, 622-23, 56 N.Y. Supp. 288, 291 (1st Dep't 1899) ; People ex rel. Municipal Gas Co. v. Rice, 138 N.Y. 151, 33 N.E. 846 (1893); Motter v. Kennett Township Elec. Co., $212 \mathrm{~Pa} .613,62$ Atl. 104 (1905); State ex rel. Thompson v. Nashville Ry. \& Light Co., 151 Tenn. 77, 90-92, 268 S.W. 120, 124 (1925); Wheeling v. Natural Gas Co., 74 W. Va. 372, 382-85, 82 S.E. 345, 349-50 (1914). Cf. People ex rel. Deneen v. People's Gas Light \& Coke Co., 205 I11. 482, 496, 68 N.E. 950, 954 (1903); Capital Gas \& Elec. Co. v. Boynton, 137 Kan. 717, 22 P.2d 958 (1933).

54. E.g., Ill. ANN. Stat. c. 111 2/3, § 10.3 (Smith-Hurd 1954).

55. Ennis Waterworks v. City of Ennis, 105 Tex. 63, 72, 144 S.W. 930, 934 (1912). See also City of San Antonio v. San Antonio Irrigation Co., 118 Tex. 154, 165, 12 S.W.2d 546, 549-50 (1929) ; Hartford Fire Ins. Co. v. Houston, 102 Tex. 317, 320-21, 116 S.W. 36, 37-38 (1909).

56. San Diego Water Co. v. San Diego Flume Co., 108 Cal. 549, 558-59, 41 Pac. 495, 498 (1895); Oakes v. Cattaraugus Water Co., 143 N.Y. 430, 38 N.E. 461 (1894); White v. City of Meadville, $177 \mathrm{~Pa} .643,35$ Atl. 695 (1896); Memphis v. Memphis Water Co., 52 Tenn. 495, 530 (1871). See also State ext rel. Thompson v. Nashville Ry. \& Light Co., 151 Tenn. 77, 90-92, 268 S.W. 120, 124 (1925).

57. 143 N.Y. 430,38 N.E. 461 (1894). 
court declared it to be valid; no reason could be found why the parties could not agree that only one application should be made for a franchise. In San Diego Water Co. v. San Diego Flume Co., ${ }^{58}$ the court approved a contract whereby one company became a distributor of water produced by another, on the ground that the resultant arrangement was not obnoxious as a monopoly because rates could be controlled by public authority. ${ }^{69}$

\section{Telegraph}

Telegraphic transmission of messages has been regulated almost as long as railroading. ${ }^{60}$ Federal legislation, sweeping in character, requires the charging of just and reasonable rates, the filing of tariffs and prohibits the granting of discriminations. The Federal Communications Commission is empowered to determine and prescribe what will constitute a just and reasonable charge and to fix the maximum and minimum or maximum or minimum charge. ${ }^{61}$ The Commission may also approve consolidations and mergers, which are otherwise forbidden. $^{62}$

Most of the early cases pertaining to the telegraph business had to do with exclusive contracts for the erection of facilities along railway rights-of-way. These decisions frequently condemned the contracts, holding them illegal either at common law or under statutory provisions, some of which dealt explicitly with the subject. ${ }^{63}$ Little mention was made of the existence of regulation and, instead, reliance was placed upon the notion that transmission of telegraphic messages is a public calling with which no exclusive arrangement should interfere. In United States v. Western Union Tel. Co., ${ }^{64}$ however, the court took cognizance of the existence of regulation, ${ }^{65}$ remarking that it was not unmindful of the distinction between enterprises inherently public in character and those of a private nature. The implication of the remark was that the antitrust laws should be applied more rigorously

58. 108 Cal. 549, 41 Pac. 495 (1895).

59. Id. at 558-62, 41 Pac. at 498-99.

60. See, e.g., Communications Act of 1934, 48 SrAT. 1070, 47 U.S.C. \$§ 201-03 (1952); ILL. ANN. STAT. c. $1112 / 3, \$ \S 1-10.5$ (Smith-Hurd 1954).

61. 48 STAr. 1072 (1934), 47 U.S.C. \& 205 (a) (1952).

62. 57 Star. 5 (1943), as amended, 47 U.S.C. $\$ 222$ (1952). See generally Note, The Telegraph Industry: Monopoly or Competition, 51 YALE L.J. 629, 637-38 (1942).

63. Union Tel. Co. v. Baltimore \& O. Tel. Co., 23 Fed. 12 (C.C.D. Ind. 1885) ; Western Union Tel. Co. v. American Tel. Co., $65 \mathrm{Ga} .160,162-63$ (1880); St. Louis \& Cairo R.R. v. Postal Tel. Co., 173 I11. 508, 524, 51 N.E. 382, 387 (1898) ; Mobile \& Ohio R.R. v. Postal Tel. Cable Co., 76 Miss. 731, 753, 26 So. 370, 374 (1899); Jones v. Carter, 45 Tex. Civ. App. 450, 101 S.W. 514 (1907). See also WPA, op. cit. supra note 36 , at LIV.

64. 53 F. Supp. 377 (S.D.N.Y. 1943).

65. 53 F. Supp. at 383. 
to public utilities than to other business. ${ }^{66}$ Only one case has been found in the state courts in which the regulated status of telegraph companies has been recognized. In In re Jackson ${ }^{67}$ the court pointed out that telegraph companies enjoy special rights, powers and privileges under regulatory legislation; it concluded that the legislature did not contemplate the existence of competition in this business and that monopoly was not condemned.

FCC v. RCA Communications, Inc., ${ }^{68}$ the leading federal decision concerned with the scope of antitrust principles in the area, involved a radio telegraphy service rather than land lines but indicates the attitude of the Commission and the courts. The Commission licensed a second communication service from Portugal and the Netherlands on the ground that the national policy favored competition whenever "reasonably feasible." The Supreme Court vacated the order of the Commission and remanded the case for a decision based more explicitly upon the statutory standards of public convenience, including competition, if the Commission deemed it desirable. The Commission, however, was not to assume that competition was a necessary ingredient of the national policy. In the course of its opinion, the Court said:

"The very fact that Congress has seen fit to enter into the comprehensive regulation of communications embodied in the Federal Communications Act of 1934 contradicts the notion that national policy unqualifiedly favors competition in communications." 69

\section{TELEPHONE}

Statutes empowering commissions to regulate telegraph companies often apply as well to telephone enterprises. Such is the case with the Federal Communications Act of 1934, which grants sweeping powers to the Federal Communications Commission. ${ }^{70}$

Despite the similarity in regulation, courts have displayed less of a tendency to exempt telephone companies from antitrust principles than they have with respect to telegraph companies. In fact, some

66. See also Union Pac. Ry. v. United States, 59 Fed. 813, 827 (8th Cir. 1894); West Virginia Transp. Co. v. Ohio River Pipe Line Co., 22 W. Va. 600, 625 (1883).

67. 57 Misc. 1, 107 N.Y. Supp. 799 (N.Y. Co. 1908).

68. 346 U.S. 86 (1953).

69. 346 U.S. at 93. On remand, the Commission found that competition was beneficial in international radio telegraphy; that it improved facilities and lowered rates. It granted the license for the competitive service again. This time the Commission's action was sustained. RCA Communications, Inc. v. FCC, 238 F.2d 24, 27 (D.C. Cir.), cert. denied, 352 U.S. 1004 (1956). Cf. Ames v. American Tel. \& Tel. Co., 166 Fed. 820 (C.C.D. Mass. 1909) ; Western Union Tel. Co. v. Chicago \& Paducah R.R., 86 Ill. 246, 252 (1877). See also State $e x$ rel. Thompson v. Nashville Ry. \& Light Co., 151 Tenn. 77, 90, 268 S.W. 120, 124 (1925).

70. See TroxeI, op. cit. supra note 42, at 100-02. 
courts have applied antitrust statutes and argued that such legislation is particularly applicable to a business following a common calling. ${ }^{71}$ In Central New York Tel. \& Tel. Co. v. Averill ${ }^{72}$ the court struck down a contract for exclusive telephone service at a hotel on this ground. $^{73}$ And in Union Trust \& Sav. Bank v. Kinloch Tel. Co. ${ }^{74}$ the court said that:

"The ordinary rule that contracts in partial restraint of trade are not invalid does not, however, apply to corporations engaged in a public business in which all the public are interested. Whatever tends to prevent competition between them or to create a monopoly is unlawful." 75

Perhaps more decisions, however, look in the opposite direction. ${ }^{76}$ Thus in McKinley Tel. Co. v. Cumberland Tel. Co ${ }^{77}$ the court considered a contract dividing territory between two telephone companies. The court refused to apply state antitrust statutes on the theory that adoption of public utility legislation evidenced a policy of protecting the public welfare through regulation. In the Illinois case of State Pub. Util. Comm'n v. Romberg, ${ }^{78}$ American Telephone \& Telegraph Company had purchased the minority stock of a competing telephone company. The purchase was approved by the Public Utility Commission over the objection of minority shareholders who argued that an article of the state constitution constituted a declaration of public policy opposed to the maintenance of monopolies and that no statute

71. United States Tel. Co. v. Central Union Tel. Co., 171 Fed. 130 (N.D. Ohio 1909), aff'd, 202 Fed. 66 (6th Cir. 1913); Union Trust \& Sav. Bank v. Kinloch Tel. Co., 258 Ill. 202, 101 N.E. 535 (1913); Louisville Home Tel. Co. v. Louisville, 130 Ky. 611, 113 S.W. 855, 861 (1908); Home Tel. Co. v. Grandy \& Neisho Tel. Co., 147 Mo. App. 216, 126 S.W. 773 (1910), overruled by Home Tel. Co. v. Sarcoxie Light \& Tel. Co., 236 Mo. 114, 139 S.W. 108 (1911); Central New York Tel. \& Tel. Co. v. Averill, 199 N.Y. 128, 92 N.E. 206 (1910).

72. 199 N.Y. 128, 92 N.E. 206 (1910).

73. 199 N.Y. at 130, 131, 92 N.E. at 207, 208. Cf. Cochranton Tel. Co. v. Public Serv. Comm'n, $263 \mathrm{~Pa}$. 506, 107 Atl. 23 (1919), disapproving the merger of two competing telephone companies under a specific clause of the state constitution.

74. 258 I11. 202, 101 N.E. 535 (1913).

75. 258 I11. at 207-08, 101 N.E. at 537.

76. Pacific Tel. \& Tel. Co. v. Anderson, 196 Fed. 699 (E.D. Wash. 1912) ; State Pub. Util. Comm'n ex rel. Clow v. Romberg, 275 Ill. 432, 114 N.E. 191 (1916); Farmers' Co-op Tel. Co. v. Boswell Tel. Co., 187 Ind. 371, 119 N.E. 513 (1918); Home Tel. Co. v. North Manchester Tel. Co., 47 Ind. App. 411, 92 N.E. 558 (1910); Cumberland Tel. \& Tel. Co. v. State ex rel. Attorney Gen., 100 Miss. 102, 54 So. 670 (1911); Whitiker v. Kilby, 55 Misc. 337, 106 N.Y. Supp. 511 (Onondago Co. 1907), aff'd mem., 122 App. Div. 895, 106 N.Y. Supp. 1149 (4th Dep't 1908) ; Mitchell v. Public Serv. Comm'n, 276 Pa. 390, 120 At1. 447 (1923); Perry Tel. Co. v. Public Serv. Comm'n, 265 Pa. 274, 279-80, 108 At1. 659, 660-61 (1919); McKinley Tel. Co. v. Cumberland Tel. Co., 152 Wis. 395,140 N.W. 38 (1913).

77. 152 Wis. 359,140 N.W. 38 (1913).

78. 275 Ill. 432, 114 N.E. 191 (1916). 
or action of the Commission thereunder could authorize the merger of competing telephone companies. ${ }^{79}$ In reply to that contention the state supreme court wrote:

"The interests of the public are not best served by competition in the telephone business, but by the consolidation and merger of competing lines and regulation as to rates and service by the State or some agency thereof." so

In Farmers' Tel. Co. v. Boswell Co., ${ }^{81}$ an Indiana case, plaintiff company had a certificate of necessity and convenience for telephone service from a state commission under a statute providing that no second certificate should be issued without affording the plaintiff a hearing with respect to the desirability thereof. Defendant secured a franchise from a town and started to install its wires. It was held that the construction of the rival telephone system should be enjoined pending issuance of a certificate by the commission. And in Home Tel. Co. v. Sarcoxie Light \& $T$ Tel. $\mathrm{Co}^{82}$ the Missouri court held valid an exclusive agreement with respect to long distance service by the operator of a local telephone exchange.

In 1949 the federal Attorney General filed an antitrust action against the American Telephone \& Telegraph Company and subsidiary corporations. The parties entered a decree by consent and hence no court ruled on the applicability of the federal antitrust statutes to the regulated telephone industry. It is, however, interesting to note that the consent decree entered sounds more like public utility regulation than antitrust-enforced competition..$^{83}$

\section{ELECTRICITY}

Production and distribution of electric power are heavily regulated. ${ }^{84}$ Municipal governments exercise a considerable measure of authority in the field. ${ }^{85}$ Most states have established administrative

79. $7 d$. at 440,114 N.E. at 194.

80. Id. at 445,114 N.E. at 196 .

81. 187 Ind. 371,119 N.E. 513 (1918).

82. 236 Mo. 114,139 S.W. 108 (1911), overruling Home Tel. Co. v. Grandy \& Neosho Tel. Co., 147 Mo. App. 216, 126 S.W. 773 (1910). See also Wayne-Monroe Tel. Co. v. Ontario Tel. Co., 60 Misc. 435, 441, 112 N.Y. Supp. 424, 428 (Wayne Co. 1908); Medina Farmers' Tel. Co. v. Medina County, 12 Ohio N.P. (n.s.) 289 (Medina Co. 1911); cases cited in Hadley, Public Utilities and the Anti-Trust Laze, 10 B.U.L. REv. 351, 362 n.26 (1930). Cf. Commonwealth Tel. Co. v. Carley, 192 Wis. 464, 468, 470,213 N.W. 469, 470, 472 (1927), in which the doctrine of primary jurisdiction was applied.

83. United States v. Western Elec. Co., CCH TRADE REg. REP. (1956 Trade Cas.) II 68, 246 (D.N.J. 1956). See Sheehan, Integration and Exclusion in the Telephone Equipment Industry, 70 Q.J. EcoN. 249, 267 (1956).

84. E.g., Ill. ÁnN. Stat. c. $1112 / 3, \S 10.3$ (Smith-Hurd Supp. 1957).

85. The Twentieth Century Fund, Electric Power and Governaent Policy $54,116(1948)$. 
agencies to control rates, ${ }^{86}$ prescribe service standards, including minimum voltage and frequency, ${ }^{87}$ require extension of service within the franchise area, prescribe uniform systems of accounting and depreciation methods ${ }^{88}$ and exercise other controls over suppliers of electric energy. Interestingly enough, several state antitrust statutes specifically exempt prices charged by electric utilities. ${ }^{89}$ Entry into the business is controlled and almost universally a certificate of necessity and convenience, or other similar license, is required from an administrative agency. Many such agencies entertain applications for competing services only when the utility serving a particular field is not furnishing adequate and satisfactory service. ${ }^{90}$

Account must also be taken of the Federal Power Act. ${ }^{91}$ Licensing of hydroelectric construction projects is a key feature of the act. ${ }^{\mathbf{9 2}}$ Transfer of facilities and merger or consolidation of utility companies are also closely controlled..$^{93}$ The Federal Power Commission exercises authority over certain rates ${ }^{94}$ and may order the establishment of connections between electric utilities and the interchange of energy between them. ${ }^{95}$ Issuance of securities must have governmental approval. $^{.6}$ And through the Public Utility Holding Company Act of $1935^{\text {}} 7$ the breaking up, now largely accomplished, of combinations of electric and other utilities is provided for. An official of the Securities and Exchange Commission, charged with enforcement of the Holding Company Act, indicated that the dissolution contemplated by that act was not designed to promote competition:

"[T]he act does not prohibit combinations if the result . . . is beneficial to the public interest. By the very nature of the utility industry, which is a regulated monopoly, combinations frequently are in the best interest of the public, provided that from the economic point of view operating economies are produced." 98

86. Id. at 254.

87. See Troxnt, op. cit. supra note 42 , at 466.

88. THE TWENTIETH CENTURY FuND, op. cit. supra note 85, at 54.

89. E.g., Colo. Rev. Stat. ANn. § 55-2-1 (1953). $17,21$.

90. E.g., Rockton Elec. Co. v. South Beloit Water, Gas \& Elec. Co., 1921 P.U.R.

91. 49 STAT. 863 (1935), 16 U.S.C. \$ 791a (1952).

92. 49 StAT. 840 (1935), 16 U.S.C. $\$ 797$ (e) (1952).

93. 41 STAT. 1068 (1927), 16 U.S.C. $\$ 801$ (1952); 49 STAT. 841 (1935), 16 U.S.C.

$\S 798$ (1952). See, e.g., In re Scranton Elec. Co., 13 P.U.R.3d 552 (1956).

94. 49 StAr. 838, 842 (1935), 16 U.S.C. $\$ \$ 796,800$ (1952).

95. 49 SiAT. 839 (1935), 16 U.S.C. $\$ 797$ (1952).

96. 49 Star. 841 (1935), 16 U.S.C. $\$ 798$ (1952).

97. 49 Star. 838 (1935), 15 U.S.C. $\$ 79$ (1952).

98. Hearings Before the Subcommittee on the Study of Corporate Mergers of the Senate, Committee on the Judiciary, 84th Cong., 2d Sess. 477 (1956). 
Under this legislation the Securities \& Exchange Commission has allowed mergers which encouraged local monopolies in the production of electricity. ${ }^{98}$ Further complicating the question of the extent to which antitrust principles are applicable to electric utilities is the fact that state, federal and municipal governments have embarked on policies of public competition with privately owned utilities. ${ }^{100}$

Many courts insist that franchises granted to electric utilities have a non-exclusive character, and hold that arrangements looking to the maintenance of monopoly are invalid. ${ }^{101}$ In other instances courts have applied antitrust principles to a variety of trade-restraining practices indulged in by electric companies. ${ }^{102}$ Other courts have found no objection to the existence of monopoly in the supply and distribution of electric power. They have approved exclusive franchises and sustained agreements eliminating competition. For example, in Idaho Power \& Light Co. v. Blomquist, ${ }^{103}$ a second electric power company sought to build a plant in a town already served by a rival. The state commission denied a certificate to the second company, and the court affirmed:

"Under [the regulatory act] it must . . . be conceded that competition with its disastrous effects is no longer needed to protect the public against unreasonable rates, hence there is no longer any justification whatever for competition or the duplication of utility plants under the pretense of preventing monopoly." 104

99. E.g., In re Derby Gas \& Elec. Corp., 100 P.U.R. (n.s.) 542 (1953) ; In re Electric Bond \& Share Co., 95 P.U.R. (n.s.) 259 (1952).

100. The TWENTner CentuRY Fund, op. cit. supra note 85, at 386-89, 395.

101. Tennessee Elec. Power Co. v. TVA, 306 U.S. 118, 139 (1939); Alabama Power Co. v. Ickes, 302 U.S. 464, 480 (1938) ; Denver v. Hubbard, 17 Colo. App. 346 68 Pac. 993 (1902) ; State v. Central Power \& Light Co., 139 Tex. 51, 161 S.W.2d 766 (1942) ; San Antonio Gas Co. v. State, 22 Tex. Civ. App. 118, 54 S.W. 289 (1899); Clarksburg Elec. Light Co. v. Clarksburg, 47 W. Va. 739, 35 S.E. 994 (1900) ; People's Land \& Mfg. Co. v. Beyer, 161 Wis. 349, 154 N.W. 382 (1915). Compare Consolidated Elec. Light Co. v. People's Elec. Light \& Gas Co., 94 Ala. 372, 10 So. 440 (1892), with City of Crosbyton v. Texas-New Mexico Util. Co., 157 S.W.2d 418, 421-22 (Tex. Civ. App. 1942).

102. Citizens' Light, Heat \& Power Co. v. Montgomery Light \& Water Power Co., 171 Fed. 553, 558 (C.C.M.D. Ala. 1909); State ex rel. Spillman v. Interstate Power Co., 118 Neb. 756, 226 N.W. 427 (1929). Recently a United States senator delivered a diatribe against an alleged "monopoly" of electric power production and distribution in the northwest United States. Hearings Before the Antitrust Subcommittee of the House Committee on the Judiciary, 84th Cong., 1st Sess., ser. 3, pt. 1, at 373-75 (1955).

103. 26 Idaho 222, 141 Pac. 1083 (1914).

104. Id. at 348-49, 141 Pac. at 1091. Accord, Illinois Power and Light Corp. v. The Commerce Comm'n, 320 I11. 427, 151 N.E. 236 (1926). Similar views prevailed in People ex rel. New York Edison Co. v. Wilcox, 207 N.Y. 86, 100 N.E. 705 (1912); Memphis Power \& Light Co.v. Memphis, 172 Tenn. 346, 112 S.W.2d 817 (1933); Holston River Elec. Co. v. Hydro Elec. Corp., 17 Tenn. App. 122, 66 S.W.2d 217 (1933) ; Hadley, supra note 82, at 354. But cf. Fogelsville \& Trexlertown Elec. Co. v. Pennsylvania Power \& Light Co., 271 Pa. 237, 114 At1. 822 (1921) (when first public utility has been granted franchise for a specific area, it cannot sit back and do nothing indefinitely). 
Another example is State ex rel. Thompson v. Nashville Ry. \& Light Co. ${ }^{105}$ Several rival companies supplying electric current had entered into exclusive arrangements to generate and distribute electricity. They formed a holding company to consolidate their interests and secured approval thereof from the state public utility commission. Thereafter an attempt was made to form a further holding company, but a bill was filed to enjoin its creation on the theory that it would violate the state antitrust statute. The court dismissed the bill, holding that the extensive powers granted the public utility commission preempted the area, rendering inapplicable the antitrust act. ${ }^{108}$

Recent litigation between a water company, a gas company (both generators and distributors of electricity) and the Federal Power Commission has brought the conflict between antitrust legislation and regulation into sharp focus. The two companies had entered into contracts for, inter alia, interchange of energy. The water company was primarily a wholesaler, the gas company primarily a retailer, their territories being contiguous. Relationships betwen the parties had been before the Commission in four proceedings and the Commission had found nothing objectionable about them. One of those proceedings had specifically raised antitrust questions. Nevertheless, in Pennsylvania Water \& Power Co. v. Consolidated Gas, Elec. Light \& Power Co., ${ }^{107}$ the agreement between the two utility companies was held invalid under the Sherman Act in that it restrained trade. The court found that, among other things, the agreement permitted the retailer to control the wholesaler's prices, expansion plans and sales territory. It wrote:

"It has been suggested that although regulated industries are not per se exempt from anti-trust laws, the statutes do not have the same application to publicly regulated industries as they do to private enterprises. . . . It is said that each utility has a legal monopoly in its own field and there is no proof that the purpose or effect of the agreement has been to raise or fix unreasonably the prices of electric energy in the area served. . . .

105. 151 Tenn. 77, 268 S.W. 120 (1925).

106. Id. at 90-91, 268 S.W. at 124. Generally in agreement are Montana-Dakota Util. Co. v. Northwestern Pub. Serv. Co., 341 U.S. 246, 252-53 (1951); Weld v. Gas and Elec. Light Comm'rs, 197 Mass. 556, 84 N.E. 101 (1908); Phelan v. Edison Elec. Illuminating $C_{0 .}, 24$ Misc. 109, 53 N.Y. Supp. 305 (1898); York Haven Water \& Power Co. v. Public Serv. Comm'n, $287 \mathrm{~Pa} .241,134$ Atl. 419 (1926). Note also that the rule requiring competitive bidding for the purchase of supplies by a municipal corporation is often relaxed when electric energy is involved, the courts taking the position that regulation takes the place of competition in that field. Mullen v. Town of Louisburg, 225 N.C. 53, 33 S.E.2d 484 (1945); Washington Fruit \& Produce Co. v. Yakima, 3 Wash. 2 d 152, 100 P.2d 8 (1940) ; Murphy v. Paull, 192 Wis. 93, 212 N.W. 402 (1927).

107. 184 F.2d 552 (4th Cir.), cert. denied, 340 U.S. 906 (1950). 
"This argument cannot be sustained. It does not give sufficient weight to the decisions, in which the anti-trust acts have been applied to utilities, or to the potential services which Penn Water might render to the public if it were relieved of the contractual restrictions upon its activities. . . . In short, the grant of monopolistic privileges, subject to regulation by governmental body, does not carry an exemption, unless one be expressly granted, from the anti-trust laws, or deprive the courts of jurisdiction to enforce them." 108

Thereafter a proceeding was instituted before the Federal Power Commission which issued its order in effect continuing the substance of the contract between the companies which the Court of Appeals for the Fourth Circuit had held invalid. That order was reviewed by the Court of Appeals for the District of Columbia and affirmed by the United States Supreme Court. ${ }^{109}$ The Court of Appeals for the District of Columbia wrote:

"The Sherman Act . . . and related laws represent an attempt to keep the channels of competition free so that prices and services are determined by the workings of a free market. They derive from the conviction that the greatest good to the greatest number will be attained by preventing monopoly, monopolizing and combinations in restraint of trade. In marked contrast is a statute such as Part II of the Federal Power Act. It evidences congressional recognition that competition can assure protection of the public interest only in an industrial setting which is conducive to a free market and can have no place in industries which are monopolies because of public grant, the exigencies of nature, or legislative preference for a particular way of doing business. In place of competition as a generalized and indirect regulator of prices and services . . . Congress has substituted a regulatory agency authorized to supervise almost every phase of the regulated company's business. . . . These contrasting objectives indicate that the antitrust laws can have only limited application to industries regulated by specific statutes." 110

In affirming, the Supreme Court said that the order of the Federal Power Commission did not require the parties to perform the contract previously held to have violated the Sherman Act. It only required that the parties conform to the terms of the Federal Power Commission's order. ${ }^{111}$ Mr. Justice Douglas wrote a bitter dissent, com-

108. Id. at $559-60$.

109. Pennsylvania Water \& Power Co. v. FPC, 193 F.2d 230 (D.C. Cir. 1951), aff'd, 343 U.S. 414 (1952).

110. 193 F.2d at 234.

111. 343 U.S. at 422. 
plaining that the Federal Power Commission had placed its blessing upon an "unholy alliance" between the two utility companies. ${ }^{112}$

The matter came back before the Court of Appeals for the Fourth Circuit under a different caption. ${ }^{113}$ The court adhered to its position that public utility companies are wholly subject to the antitrust laws and held invalid a contract between the parties creating a joint subsidiary, over the argument of intervenor Federal Power Commission that it had the right to grant exemption from the antitrust laws to a water power utility. ${ }^{114}$

\section{MOTOR CARRIERS}

States have engaged in extensive regulation of all motor vehicles, whether operated for pleasure or profit, with a view to the maintenance of safety on the highways. In addition, many have enacted measures providing "economic" regulation. ${ }^{115}$ Thus a statute provides that the Illinois Commerce Commission shall fix rates for common carriers and minimum rates for contract carriers. ${ }^{118}$ Common carriers can only operate if they have certificates of necessity and convenience while contract carriers must have permits. ${ }^{117}$ The Commission is to control merger, transfer and the acquisition of control of carriers. ${ }^{118}$ The interstate aspects of trucking are controlled by the Interstate Commerce Commission under the terms of Interstate Commerce Act. ${ }^{119}$ That statute provides that the federal tribunal may fix both maximum and minimum or maximum or minimum rates for common carriers and minimum rates for contract carriers. ${ }^{120}$ It also provides for detailed regulation of most of the same aspects of trucking covered by state law, including service, safety, licensing, financing and the like. ${ }^{121}$ An inter-

112. Id. at 424-26.

113. Consolidated Gas, Elec. Light \& Power Co. v. Pennsylvania Water \& Power Co., 194 F.2d 89 (4th Cir.), cert. denied, 343 U.S. 963 (1952).

114. 194 F.2d at 95, 98. The same tribunal, however, lacked the courage to award treble damages to the company which it had found victimized by the illegal contract. Pennsylvania Water \& Power Co. v. Consolidated Gas, Elec. Light \& Power Co., 209 F.2d 131 (4th Cir. 1953), cert. denied, 347 U.S. 960 (1954). Applying the doctrine of in pari delicto, the court held that Pennsylvania Water could not recover treble damages from Consolidated Gas by reason of the violation of the Sherman Act, despite Kiefer-Stewart Co. v. Joseph E. Seagram \& Sons, Inc., 340 U.S. 211 (1951). Subsequent proceedings are reported as $R e$ Pennsylvania Water \& Power Co., 9 P.U.R.3d 167 (1955).

115. E.g., Ill. ANn. Stat. c. 95 1/2, §§ 282.1-.30 (Smith-Hurd Supp. 1957).

116. $I d . \S 282.4$.

117. Id. $\S \S 282.5-6$.

118. Id. $\$ 282.13$.

119. 49 STAT. 543 (1935), as amended, 49 U.S.C. $\S 301-27$ (1952).

120. 49 Srar. 558, 561 (1935), as amended, 49 U.S.C. $\S 316$ (e), 318 (b) (1952).

121. See Meck \& Bogue, Federal Regulation of Motor Carrier Unification, 50 YALE L.J. 1376, 1381-83 (1941). 
esting feature of both state and federal licensing is the existence of "grandfather" clauses permitting those already in the business at the time regulation begins to receive certificates of necessity and convenience without Commission findings of public need. ${ }^{122}$

We find surprisingly little litigation with respect to the applicability of antitrust laws to the operations of motor carriers. Norfolk So. Bus Corp. v. Virginia Dare Transp. Co. ${ }^{123}$ appears to hold squarely that truckers are subject at the same time to the Interstate Commerce Act and the Sherman Act. The court held illegal under the Sherman Act a contract between two motor carriers providing one with free terminal and handling service at the expense of the other if the first restricted its operations to two round trips per week between named points. If it did not so restrict itself, the first carrier was required by the contract to pay for the terminal and handling services. Both companies operated on the same route. The court did not make it clear whether it thought approval of the contract by the ICC would have washed out the Sherman Act violation, but held that the contract violated the Interstate Commerce Act because not submitted to the ICC for prior approval. ${ }^{124}$

The Supreme Court's attitude toward Commission-approved arrangements is indicated by McLean Trucking Co. v. United States ${ }^{125}$ in which it affirmed the lower court's refusal to set aside a Commission order permitting the merger of seven east coast truckers. The Commission had made a finding with respect to the merger's effect upon competition, but had taken this into account as merely one of several factors in determining the public interest. In approving this procedure, the Court rejected the argument that the Interstate Commerce Act should be interpreted to permit mergers having an adverse effect upon competition only when absolutely necessary to effectuate the national transportation policy. ${ }^{126}$ Justice Douglas, dissenting, would have resolved the apparent conflict between the Sherman Act and the Interstate Commerce Act by adopting the interpretation rejected by the majority. ${ }^{127}$

Another case of interest is State ex rel. Dep't of Pub. Works $v$. Inland Forwarding Corp. ${ }^{128}$ The state constitution forbade monopoly,

122. George, Supreme Court Views Federal Authorization and Merging of Motor Carriers, 26 LAND ECoN. 183 (1950).

123. 159 F.2d 306 (4th Cir.), cert. denied, 331 U.S. 827 (1947).

124. Id. at 311 .

125. 321 U.S. 67 (1944).

126. Id. at 78-79. Cf. ICC v. Parker, 326 U.S. 60 (1945), one of a series of decisions involving the power of the ICC to license railways to enter into auxiliary trucking services.

127. 321 U.S. at 94.

128. 164 Wash. 412,2 P.2d 888 (1931). 
but a statute required the grant of a certificate of public convenience and necessity before one could operate freight trucks on the highway. A second certificate over the same route could be issued only when the existing service was found to be inadequate. Holding the statute valid, the court found that it did not authorize the type of monopoly proscribed by the constitution. ${ }^{129}$

\section{Water Carriers}

Operators of steamship lines, barge routes and the like may be subject to regulation under state statutes. ${ }^{130}$ As a practical matter most of the regulatory activity is centered in the federal government where jurisdiction is divided; domestic water carriers are subject to control under the terms of the Interstate Commerce Act ${ }^{131}$ and those engaged in foreign commerce are subject to control by the Maritime Commission under the terms of the Shipping Act ${ }^{132}$ and the Merchant Marine Act. ${ }^{133}$ Most of the litigation with which we are concerned appears to have arisen under the Shipping Act. That statute prohibits discriminatory rates, including exclusive dealing rebates and the like. ${ }^{134}$ It provides that common carriers by water are to file copies of agreements with rival carriers and that the Commission may revoke such agreements, which shall only be lawful if approved. It then provides: "Every agreement, modification, or cancellation lawful under this section shall be excepted from [the antitrust laws]." 135 Subsequent sections prohibit discriminatory charges ${ }^{136}$ and empower the Maritime Commission to prescribe "just and reasonable" rates. ${ }^{137}$

In the absence of statute, water carriers appear to be subject to the normal common-law rules against restraints of trade. Thus in Anderson $v$. Jett, ${ }^{138}$ the court declared illegal an agreement between owners of competing steamboats to share profits by a formula set forth in the

129. Id. at 419-22, 2 P.2d at 891-92.

130. E.g., ILL. ANN. Srar. c. $1112 / 3$, $\S 10.3,10.4$ (Smith-Hurd 1954).

131. 54 STAT. 929 (1940), 49 U.S.C. $\$ \$ 901-23$ (1952).

132. 39 Stat. 728 (1916), as amended, 46 U.S.C. $\$ \$ 801-42$ (1952).

133. 41 STAT. 988 (1920), as amended, 46 U.S.C. $\$ \$ 861-89$ (1952).

134. 39 Sirar. 733 (1916), as amended, 46 U.S.C. $\S 812$ (1952).

135. 39 Stat. 733 (1916), as amended, 46 U.S.C. $\$ 814$ (1952).

136. 39 STA1. 734 (1916), as amended, 46 U.S.C. \$§ 815-16 (1952).

137. 39 Srar. 735 (1916), as amended, 46 U.S.C. $\$ 817$ (1952). Section 29 (b) of the Merchant Marine Act provides: "Nothing contained in the antitrust laws ... shall be construed as declaring illegal an association entered into by marine insurance companies for the following purposes: To transact the marine insurance and reinsurance business in the United States and in foreign countries and to reinsure or otherwise apportion among its membership the risks undertaken by such association or any one of the component members." 41 STAT. 1000 (1920), 46 U.S.C. $\$ 885$ (b) (1952).

138. $89 \mathrm{Ky} .375,12 \mathrm{~S} . \mathrm{W}$. 670 (1889). Under a specific constitutional clause a similar result was reached in Manson v. Hunt, 82 Wash. 291, 144 Pac. 45 (1914). 
contract. In several cases the courts appear to have assumed that water carriers were subject to the prohibitions of the antitrust laws without expressly considering the existence of regulation or discussing the issue. ${ }^{139}$

Other courts have been more tolerant of restraints in this field. ${ }^{140}$ What has revolutionized the application of the antitrust statutes to water carriers, however, is the doctrine of primary jurisdiction. In a series of decisions of gradually expanding scope, the courts have held that antitrust suits should be dismissed in favor of proceedings before the regulatory commissions. ${ }^{141}$ As matters stand, therefore, many litigants, including the Attorney General, seeking to rely upon rights created by antitrust statutes, will find themselves relegated to litigation before an administrative agency charged with the economic regulation of the water carrier defendant. Although such decisions do not expressly negative the applicability of antitrust statutes, they imply a broad tolerance of agency-approved conduct.

\section{AIr CARrIERS}

State control of aviation is relatively insignificant. ${ }^{142}$ The important federal statute is the Civil Aeronautics Act ${ }^{143}$ which provides for comprehensive regulation of the air transport industry. Among other matters, the Civil Aeronautics Board is directed to see that every air carrier maintains just and reasonable rates. ${ }^{144}$ The Board controls mergers and abandonments. ${ }^{145}$ A section of the act contains detailed prohibitions against diversification on the part of air carriers, preventing them from becoming associated with rail, water and motor carriers. ${ }^{146}$ Air carriers are also forbidden to become affiliated with manufacturers

139. United States v. Inter-Island Nav. Co., 87 F. Supp. 1010 (D. Hawaii 1950); Isbrandtsen Co. v. United States, 81 F. Supp. 544 (S.D.N.Y. 1948), appeal dismissed, 336 U.S. 941 (1949). Cf. Stewart v. Erie \& Western Transp. Co., 17 Minn. 348 (1871); Lough v. Outerbridge, 143 N.Y. 271,38 N.E. 292 (1894).

140. Wiggins Ferry Co. v. Chicago \& Alton R.R., 73 Mo. 389, 407-08, 410-11 (1881) ; Kitsap County Transp. Co. v. Manitou Ferry Ass'n, 176 Wash. 486, 30 P.2d 233 (1934).

141. Far East Conference v. United States, 342 U.S. 570, 573-76 (1952); United States Nav. Co. v. Cunard S.S., 284 U.S. 474, 481-82 (1932); American Union Transp., Inc. v. River Plate \& Brazil Conferences, 126 F. Supp. 91 (S.D.N.Y. 1954), aff'd per curiam, 222 F.2d 369 (2d Cir. 1955) ; United States v. Alaska S.S., 110 F. Supp. 104 (W.D. Wash. 1952). Cf. Isbrandtsen Co. v. United States, 96 F. Supp. 883, 889 (S.D.N.Y. 1951), aff'd by an equally divided Court sub nom. Rederi v. Isbrandtsen Co., 342 U.S. 950 (1952).

142. E.g., Ill. ANn. Stat. c. 111 2/3, \& 10.3 (Smith-Hurd 1954) ; Ill. Ann. Stat. c. $151 / 2, \& 22$ (Smith-Furd 1951).

143. 52 STAT. 973 (1938), 49 U.S.C. $\$ \S 401-722$ (1952).

144. 52 STAT. 993 (1938), 49 U.S.C. $\$ 484$ (a) (1952.)

145. 52 StAT. 987, 1001 (1938), 49 U.S.C. $\$ \$ 481(\mathrm{k}), 488$ (1952).

146. 52 STar. 1002 (1938), 49 U.S.C. $\S 489$ (1952). 
of aircraft. In a somewhat contradictory vein, the statute appears to contemplate that air carriers may make price-fixing agreements with their competitors because it provides for the filing of such contracts with the Board. ${ }^{147}$ One section stipulates that in the exercise of its powers, the Board shall consider the following, among other things, as being in the public interest:

"(d) Competition to the extent necessary to assure the sound development of an air-transportation system properly adapted to the needs of the foreign and domestic commerce of the United States, of the Postal Service, and of the national defense. . . ."148

Any person affected by an order made under specified sections of the act is relieved from the operation of the antitrust laws. ${ }^{149}$ Lastly, it should be observed that provision is made for the payment of subsidies to air carriers. ${ }^{150}$ In a recent year as much as $\$ 25,000,000$ was so expended, ${ }^{151}$ thus giving the Government a substantial stake in the economic well-being of the industry.

As noted above, the federal legislation contains an express exemption from antitrust coverage and the courts have had at least one opportunity to apply it. ${ }^{152}$ Activity outside the express exemption contained in the statute has been considered within the purview of the antitrust laws, ${ }^{153}$ unless a specific remedy is granted under the terms of the Civil Aeronautics Act. In Apgar Travel Agency, Inc. v. International Ass'n, ${ }^{154}$ for example, which alleged a conspiracy to destroy plaintiff's business because of its representation of non-scheduled carriers, the court denied defendant's motion to dismiss the case on the ground that primary jurisdiction existed in the Civil Aeronautics Board. Instead, it was held that the suit should be stayed pending action before that tribunal. Recognizing that the economic conduct of air carriers was a matter subject to the detailed and comprehensive regulation of the Board ${ }^{155}$ and that national policy did not favor unbridled competition in the industry, the court said that the antitrust laws were superseded by regulatory statutes only to the extent of the repugnancy

147. 52 STAT. 1004 (1938), 49 U.S.C. $\$ 492$ (1952).

148. 52 STAT. 980 (1938), 49 U.S.C. $\$ 402$ (1952).

149. 52 STAT. 1004 (1938), 49 U.S.C. $\$ 494$ (1952).

150. 52 STAT. 998 (1938), 49 U.S.C. $\$ 486$ (1952).

151. Wircox, Public Policy Toward Business 637-38 (1955).

152. Putnam v. Air Transp. Ass'n, 112 F. Supp. 885 (S.D.N.Y. 1953).

153. S.S.W., Inc. v. Air Transp. Ass'n, 191 F.2d 658, 664 (D.C. Cir. 1951) ; Apgar Travel Agency, Inc. v. International Air Transp. Ass'n, 107 F. Supp. 706 (S.D.N.Y. 1952) ; Slick Airways, Inc. v. American Airlines, Inc., 107 F. Supp. 199 (D.N.J. 1951), rehearing dentied, 107 F. Supp. 199 (D.N.J. 1952).

154. 107 F. Supp. 706 (S.D.N.Y. 1952).

155. Id. at 709. 
between them. ${ }^{158}$ Since the Civil Aeronautics Act made no provision for the remedy of damages, that remedy provided under the antitrust laws remained unaffected. ${ }^{157}$ In Slick Airways, Inc. v. American Airlines, $I n c .{ }^{158}$ the court denied a motion to dismiss on the ground primary jurisdiction existed in the Civil Aeronautics Board and in effect held that the case should proceed. It found that the Board enjoyed no power to award damages or reparations for violation of the Civil Aeronautics Act ${ }^{159}$ and hence concluded that a remedy must be available to the plaintiff in the courts. However, in S. S. W., Inc. v. Air Transp. $A s s^{\prime} n^{160}$ it was held that although plaintiff had a remedy in the courts for damages, the doctrine of primary jurisdiction required that with respect to the injunction sought the case be stayed pending Civil Aeronautics Board disposition of proceedings seeking injunctive relief. There emerges, therefore, a reasonably clear picture that the antitrust laws are considered fully applicable to air carriers unless the activity complained of falls precisely within the scope of the statutory exemption. If, however, the relief sought could be afforded by the Civil Aeronautics Board, the parties will be required to proceed before that tribunal and exhaust their remedies there before securing judicial relief.

\section{TRANSIT}

Transportation of persons by means of streetcars, buses and other vehicles has long been the subject of governmental regulation. ${ }^{161}$ There has been considerable litigation with respect to the application of antitrust principles to regulated transit systems.

Some decisions reflect the view that exclusive franchises are illegal either at common law or under specific constitutional provisions. ${ }^{162}$ In Jones $v$. Carter, ${ }^{163}$ the original land owner platted a town and reserved to himself the right to operate street railways, a telephone system, telegraph system, waterworks, gas works, steam heat service, sewage service, electric service and storm sewers. The reservation was held unlawful.

156. Id. at 711 .

157. Ibid.

158. 107 F. Supp. 199 (D.N.J. 1951).

159. Id. at 205.

160. 191 F.2d 658 (D.C. Cir. 1951).

161. E.g., Ill. Ann. Stat. c. 111 2/3, §§ 10.3, 10.4 (Smith-Hurd 1954).

162. Birmingham \& Pratt Mines Street Ry., 79 Ala. 465 (1885) ; Jones v. Carter, 45 Tex. Civ. App. 450, 101 S.W. 514 (1907).

163. 45 Tex. Civ. App. 450, 101 S.W. 514 (1907). 
Other decisions treat agreements between operators of rival street railways systems as subject to antitrust principles. ${ }^{164}$ In several instances the courts have discussed the issue as if antitrust statutes were applicable but reached the conclusion that the contract or practice in question did not fall within the prohibitions of such legislation. ${ }^{165}$ It is also worth noting that as early as 1889 specific state antitrust statutes forbade the consolidation of street railways. ${ }^{160}$

The weight of authority plainly looks in the other direction. ${ }^{167}$ Most of these cases involve the grant of certificates of necessity and convenience or the enjoining of rival transportation service. Thus in Princeton Power Co. v. Calloway, ${ }^{168}$ an established electric inter-urban railway was granted an injunction against the competition of jitneys on a parallel route. Monongahela West Penn Pub. Serv. Co. v. State Road Comm'n, ${ }^{160}$ a West Virginia case, held that it was improper to grant a certificate of convenience and necessity to a new bus line when the existing bus lines and railways provided adequate service.

The Illinois decisions are particularly instructive. In South Chicago City Ry. v. Calumet Elec. Street $R y .,{ }^{170}$ the Illinois court held that proprietors of transit systems should compete with each other and

164. Trust Co. v. State, 109 Ga. 736, 35 S.E. 323 (1900); South Chicago City Ry. v. Calumet Elec. Street Ry., 171 Ill. 391, 49 N.E. 576 (1898); Schultz v. Johnson, 110 N.J. Eq. 566 (Ct. Err. \& App. 1932) ; Scott v. Farmers' \& Merchants Nat'l Bank, 97 Tex. 31, 75 S.W. 7 (1903).

165. Fleetway, Inc. v. Public Serv. Interstate Transp. Co., 72 F.2d 761 (3d Cir. 1934); Southern Elec. Securities Co. v. State, 91 Miss. 195, 44 So. 785 (1907); Brooklyn Elevated R.R. v. Brooklyn B. \& W.E. R.R., 23 App. Div. 29, 48 N.Y. Supp. 665 (2d Dep't 1897), modified, 23 App. Div. 625, 48 N.Y. Supp. 1101 (2d Dep't 1897). Cf. State ex rel. Pitcairn v. Public Serv. Comm'n, 232 Mo. App. 535, 111 S.W.2d 222 (1937), in which the court said that a certificate of convenience and necessity should be issued to a bus line even though rail service were adequate, if the commission found public convenience would be promoted. Id. at 545, 111 S.W.2d at 228-29.

166. WPA, State ANTitrust Laws lv (Martin ed. 1940).

167. Continental Securities Co. v. Interborough Rapid Transit Co., 207 Fed. 467 (S.D.N.Y. 1913) ; Burgess v. Mayor of Brockton, 235 Mass. 95, 126 N.E. 456 (1920); Matter of Interborough-Metropolitan Co., 125 App. Div. 804, 110 N.Y. Supp. 186 (1st Dep't 1908); Cincinnati Traction Co. v. Public Util. Comm'n, 112 Ohio St. 699 , 148 N.E. 921 (1925); Day v. Tacoma Ry. \& Power Co., 80 Wash. 161, 141 Pac. 347 (1914); Wood v. Seattle, 23 Wash. 1, 62 Pac. 135 (1900); Monongahela West Penn Pub. Serv. Co. v. State Road Comm'n, 104 W. Va. 183, 139 S.E. 744 (1927); Pocahontas Transp. Co. v. Craft, 100 W. Va. 240, 130 S.E. 468 (1925) ; Princeton Power Co. v. Calloway, 99 W. Va. 157, 128 S.E. 89 (1925). Other cases apparently taking the same view include Wilmington City Ry. v. Wilmington \& Brandywine Ry., 8 Del. Ch. 468, 46 Atl. 12 (Ch. 1900); People v. Chicago, 349 Ill. 304, 182 N.E. 419 (1932) ; Chicago Motor Bus Co. v. Chicago Stage Co., 287 I11. 320, 122 N.E. 477 (1919); Venner v. Chicago City Ry., 258 Ill. 523, 101 N.E. 949 (1913); Indianapolis Cable Street Ry. v. Citizens Street Ry., 127 Ind. 369, 24 N.E. 1054 (1890); Harrison v. Big Four Bus Lines, $217 \mathrm{Ky} .119,288$ S.W. 1049 (1926); State ex rel. Thompson v. Nashville Ry. \& Light Co., 151 Tenn. 77, 268 S.W. 120 (1924); Note, Recent Statntes Relating to Carriers, 24 CoLUM. L. REv. 528 (1924).

168. 99 W. Va. 157, 128 S.E. 89 (1925).

169. 104 W. Va. 183, 139 S.E. 744 (1927). Cf. Whittaker v. Southeastern Greyhound Lines, $314 \mathrm{Ky} .131,234$ S.W.2d 174 (1950); State v. Queen City Coach Co., 233 N.C. 119, 63 S.E.2d 113 (1951); Intercity Auto Stage Co. v. Bothell Bus Co., 139 Wash. 674,247 Pac. 1040 (1926).

170. 171 I11. 391,49 N.E. 576 (1898). 
that contracts leading toward monopoly were invalid. Apparently that decision has been overruled sub silentio, for many recent decisions reach contrary results. Thus West Suburban Transp. Co. v. Chicago \& West Tozens $R y .{ }^{171}$ held that no license should be granted to operate a competing bus line when an existing trolley line provided adequate service.

"Where one company can serve the public conveniently and efficiently it has been found from experience that to authorize a competing company to serve the same territory ultimately results in requiring the public to pay more for transportation, in order that both companies may receive a fair return on the money invested and the cost of operation." 172

There presently appears to be little scope for the application of antitrust principles in litigation involving the operation of transit lines.

\section{TAXIS}

It has long been the practice to license and regulate operators of cabs, whether horse or motor propelled. Today authority to control taxi cabs is perhaps most frequently exercised by municipal corporations, but state commissions sometimes enjoy such powers. ${ }^{173}$ Most of the decisions involving the hack men have turned upon the validity of exclusive contracts for the privilege of standing at railway depots.

Some decisions hold exclusive rights and similar arrangements illegal, either at common law or under statutes. ${ }^{174}$ In one case, United States v. Yellow Cab Co., ${ }^{175}$ the federal antitrust laws were applied directly to companies operating taxi cabs: However, only passing reference was made to the licensing of the cabs and the regulation thereof; the case focused on sales made to cab-operating companies by affiliated manufacturing concerns. The case was sent back for trial and the district court found the facts to favor the defendants. ${ }^{176}$

171. 309 III. 87,140 N.E. 56 (1923).

172. Id. at 92, 140 N.E. at 58. Accord, Chicago Rys. v. Commerce Comm'n, 336 I11. 51, 167 N.E. 840 (1929) ; Bartonville Bus Line v. Eagle Motor Coach Line, 326 II1. 200, 157 N.E. 175 (1927) ; Choate v. Commerce Comm'n, 309 I11. 248, 141 N.E. 12 (1923).

173. E.g., Irl. AnN. StaT. c. 24, § 23-51 (Smith-Hurd 1942).

174. North Little Rock Transp. Co. v. North Little Rock, 207 Ark. 976, 184 S.W. 2d 52 (1944) ; Indianapolis Ry. v. Dohn, 153 Ind. 10, 53 N.E. 937 (1899); J.H. Fields v. Holland \& Son, 158 Ky. 544, 165 S.W. 699 (1914) ; Palmer Transfer Co. v. Anderson, $131 \mathrm{Ky} .217,115$ S.W. 182 (1909); McConnell v. Pedigo \& Hays, $92 \mathrm{Ky} .465$, 18 S.W. 15 (1892).

175. 332 U.S. 218 (1947).

176. 80 F. Supp. 936 (N.D. Ill. 1948), aff'd, 338 U.S. 338 (1949). Mr. Justice Black and Mr. Justice Reed dissented from the affirmance saying that the evidence indicated higher prices had been paid for cabs by operating companies than if they had been purchased on the free market. This argument suggests that the defendants were seeking to avoid the impact of regulation by inflating their costs. $C f$. Yellow Cab Co. 
Perhaps the greater number of decisions favors the view that regulation precludes the application of antitrust principles. In any event the United States Supreme Court so found the weight of authority thirty years ago in Black \& White Taxicab Co. v. Brown and Yellow Taxi$c a b C 0 .{ }^{177}$ That case did not deal directly with the effect of regulation upon antitrust principles but the Court sustained an exclusive agreement saying that there was no showing of a lack of proper public service resulting from the contract. ${ }^{178}$ Despite the number of cases approving exclusive agreements and the like in private suits, it is not wholly clear that a majority of the courts would hold proprietors of taxicabs to be exempt from antitrust prosecution at the suit of a state or federal attorney general. The opinions do not purport to rest upon the existence of regulation and the one important federal antitrust case does not even consider the possibility that an exemption would be available. ${ }^{179}$ Hence the state of the law in this area must be considered uncertain.

\section{BROADCASTING}

As in the case of aeronautics, the federal government exercises almost exclusive control over the transmission of AM, FM and TV broadcasts. ${ }^{180}$ The statute under which the Federal Communications Commission operates is the Comunications Act of $1934,{ }^{181}$ a principal feature of which is its provision for the licensing of broadcasters. ${ }^{182}$ The number of frequencies upon which messages may be transmitted is limited and hence licensing is necessary to prevent signal interference. Since the power and location of the stations may create interference, the Commission also has power to classify radio stations and to pre-

v. Chicago, 396 Ill. 388, 71 N.E.2d. 652 (1947), in which the court sustained the validity of an ordinance limiting the number of taxis, fixing the fares that might be charged, regulating the hours of the drivers and the like on the ground that the ordinance did not confer an illegal monopoly because there were many licensees and the number could be increased after hearings and findings of public necessity. See also Pennsylvania Co. v. Chicago, 181 I1l. 289, 54 N.E. 825 (1899).

177. 276 U.S. 518, 526-29 (1928).

178. Id. at 529. Among the decisions upon which the Supreme Court relied were Union Depot \& Ry. Co. v. Meeking, 42 Colo. 89, 94 Pac. 16 (1908); Old Colony R.R. v. Tripp, 147 Mass. 35, 17 N.E. 89 (1888); Thompson's Express Co. v. Whitemore, 88 N.J. Eq. 535, 102 At1. 692 (Ct. Err. \& App. 1917) ; Brown v. N.Y.C. \& H.R.R., 75 Hun. 355 (N.Y. Sup. Ct. 1894); Rose v. Public Serv. Comm'n, 75 W. Va. 1, 83 S.E. 85 (1914). Cf. Hart v. Atlanta Terminal Co., 128 Ga. 754, 58 S.E. 452 (1907); Capitol Taxicab Co. v. Cermak, 60 F.2d 608, 612 (N.D. IIl. 1932); Hedding v. Gallagher, 72 N.H. 377, 57 Atl. 225 (1903) ; Parsons v. Galveston, 125 Texas 568, 84 S.W.2d 996 (1935) ; Gill v. Dallas, 209 S.W. 209 (Tex. Civ. App. 1919). See also Delaware, Lackawanna \& Western R.R. v. Morristown, 276 U.S. 182, 194 (1928).

179. United States v. Yellow Cab Co., 332 U.S. 218 (1947).

180. Troxed, Economics of Public Utmitres 509 (1947).

181. 48 Stat. 1081-82 (1934), as amended, 47 U.S.C. $\$ \S 301-03$ (Supp. IV, 1957). 182. 48 Star. 1081 (1934), as amended, 47 U.S.C. § 301 (Supp. IV, 1957). 
scribe the nature of their service, to fix the locations of their transmitters, to assign frequencies, to regulate their apparatus, to fix the power they may employ and to specify the times during which they may operate. ${ }^{183}$ It is directed to deny a license to any one who has been adjudged to have monopolized radio communication. The statute also specifically provides:

"All laws of the United States relating to unlawful restraints and monopolies and to combinations, contracts, or agreements in restraint of trade are hereby declared to be applicable to ... interstate or foreign radio communications." 184

Upon conviction of a violation of the antitrust laws a licensee under the statute is to lose his permission to broadcast. Furthermore, a radio licensee is not to acquire telephone, telegraph or cable interests if the effect is substantially to lessen competition. ${ }^{185}$ While the Commission enjoys power to restrict entry into the business, it does not fix the prices at which the products (advertising) may be sold; the statute specifically contemplates the continuance of competition in broadcasting. In practice, the Commission grants licenses freely, ${ }^{186}$ but sometimes withholds a permit even though a frequency is available when the station does not appear to enjoy a reasonable expectation of success. It has also adopted rules limiting the number of licenses available to any party (including parties under common ownership) in an effort to avoid what it refers to as "concentration of control." 187 Particular attention has been paid to network affiliation of radio and television broadcasters. Under one section the Commission is empowered to make regulations applicable to the licensees with respect to their network affiliations. ${ }^{188}$ As a result, the Commission has prohibited exclusive network affiliation, required that contracts for affiliation be limited to a two year term, controlled "option time" and insisted that the station proprietors have the right to reject programs. ${ }^{189}$

183. 48 Stat. 1082 (1934), as amended, 47 U.S.C. $\$ 303$ (Supp. IV, 1957).

184. 48 SrAT. 1087 (1934), as amended, 47 U.S.C. $\$ 313$ (Supp. IV, 1957).

185. 48 STAT. 1087 (1934), as amended, 47 U.S.C. §§ 313-14 (Supp. IV, 1957).

186. Troxer, op. cit. supra note 180 , at $515-16$. There has been much controversy and some litigation with respect to the licensing of proprietors of newspapers to operate radio and television stations. See Stahiman v. FCC, 126 F.2d 124, 127 (D.C. Cir. 1942). Cf Clarksburg Publishing Co. v. FCC, 225 F.2d 511 (D.C. Cir. 1955). See also Goldin, Economic and Regulatory Problems in the Broadcast Field, 30 LAND ECON. 223, 232 (1954).

187. 47 C.F.R. $\S \S 3.35,3.240$ (Supp. 1957).

188. 48 StAT. 1082 (1934), as amended, 47 U.S.C. $\$ 303$ (i) (Supp. IV, 1957).

189. 47 C.F.R. $\$ \$ 3.131-133$ (Supp. 1957), sustained in United States v. Storer Broadcasting Co., 351 U.S. 192 (1956). In recent years there has been bitter controversy with respect to the allocation of "channels" for broadcasting of television programs. The Commission "intermixed" VHF licenses with UHF licenses. Since the UHF 
In view of the statutory provision declaring that the antitrust laws should be applicable to the broadcasting business, the courts usually hold the industry fully subject to that legislation. The Court held in the leading case of FCC v. Sanders Bros. Radio Station, ${ }^{190}$ that resulting economic injury to an existing station is not an element the Commission must weigh in passing on applications for a new broadcasting license. In the course of the opinion the Court noted the difference in treatment accorded telephonic and telegraphic communication and broadcasting by the Communications Act, broadcasting being recognized as a field of free competition. ${ }^{191}$

Nevertheless, one notes some reluctance to apply antitrust legislation vigorously against broadcasters. In the first place, Federal Broadcasting System v. American Broadcasting Co ${ }^{192}$ hints that the doctrine of primary jurisdiction may be applicable. Plaintiff operated a broadcasting station which had been served by two networks, but according to the allegations of the complaint the plaintiff refused to enter into exclusive affiliation with either one. Thereafter both networks made other arrangements and plaintiff was not able to secure any network programs. Suit was brought against several major networks alleging a conspiracy to drive the plaintiff out of business, and seeking an injunction pendente lite to compel the rendition of network service. An injunction was denied and the court of appeals affirmed, saying:

"We think it improper to grant a preliminary injunction upon the charge that the networks have unlawful 'exclusive' contracts with their stations where the Federal Communications Commission, after protracted hearings and consideration not only of the general public interest but of the Sherman Anti-Trust Act, has specifically sanctioned many of the important terms of the affiliation contracts at present in use and the defendants have given reasonable grounds for denying their exclusiveness or illegality." 193

signal is weaker than the VHF signal and since most receivers are not equipped to UHF transmission, the proprietors of the UHF stations have been handicapped. There has, therefore, been less utilization of the UHF frequency range than might have been possible had no licenses been granted to the VHF stations.

190. 309 U.S. 470 (1940).

191. Id. at 474. $C f$. FCC v. Allentown Broadcasting Corp., 349 U.S. 358, 362 (1955); Clarksburg Publishing Co. v. FCC, 225 F.2d 511, 518-19 (D.C. Cir. 1955). By way of contrast, common carriers engaged in the transmission of messages by radiotelegraph appear to enjoy a regulated monopoly status. FCC v. RCA Communications, Inc., 346 U.S. 86 (1953); Mackey Radio \& Tel. Co. v. FCC, 97 F.2d 641 , 643 (D.C. Cir. 1938). See also National Broadcasting Co. v. United States, 319 U.S. 190, 222 (1943); Television Transmission, Inc. v. Public Util. Comm'n, 47 Cal. 2d 82, 301 P.2d 862 (1956) ; H.R. REP. No. 607, 85th Cong., 1st Sess. 95-97 (1957); Hansen, Statement on Antitrust Activities in the Field of Television, 2 ANTITRUST BULL. 99, 105 (1956).

192. 167 F.2d 349 (2d Cir.), cert. denied, 335 U.S. 821 (1948).

193. Id. at 352 . 
In the second place, while it is often-repeated doctrine that licensees have no property interests in the transmission channels assigned to them by the Commission, the cases appear to recognize that the licensee has at least a right to a hearing before the channel is taken and awarded to a rival. ${ }^{194}$ And not too long ago the Attorney General of the United States wrote as follows:

“. . . we observe that the concepts 'regulation' and 'free competition' . . . are anti-thetical. . . . Maintenance of a completely competitive market requires that opportunity to enter the market be unrestricted. The telecasting business is not an industry in which unrestrained freedom to enter exists. . . . Consequently, the interpretation of the antitrust laws in cases involving telecasters must take into account the fact that entry is regulated by the Government." 195

\section{INSURANCE}

Prior to 1944 control over insurance companies was exclusively a concern of state governments. Almost every state had enacted legislation designed to protect policyholders, and administrative officers were active in varying degrees to that end. ${ }^{106}$ The Illinois statute, which is perhaps typical, provides for detailed control over insurance companies, including provisions otherwise commonly found in business corporation statutes with respect to minimum capital and the like. The state controls the forms of policies issued, prohibits misrepresentations with respect to such policies, prescribes rates for different types of insurance and requires the filing of tariffs. ${ }^{197}$ Deceptive acts and practices are forbidden, the director of insurance may control interlocking directorates and discrimination in the payment of premiums is prohibited. ${ }^{198}$

Notwithstanding the fact that the states have long regulated insurance in one degree or another, the courts almost always held insurance companies subject to antitrust principles. Indeed, some

194. Clarksburg Publishing Co. v. FCC, 225 F.2d 511 (D.C. Cir. 1955) ; Metropolitan Television Co. v. United States, 221 F.2d 879 (D.C. Cir. 1955); Colorado Radio Corp. v. FCC, 118 F.2d 24, 26 (D.C. Cir. 1941). See also FCC v. Sanders Bros. Radio Station, 309 U.S. 470, 476 (1940); Note, The "Fringe Area" of Public Utilities, 58 W. VA. L. REv. 390, 397 (1956).

195. Hearings Before the Senate Committee on Interstate and Foreign Commerce, 84th Cong., 2d Sess., pt. 2, at 404 (1956). But cf. Mansfield Journal Co. v. FCC, 180 F.2d 28, 33 (D.C. Cir. 1950).

196. E.g., Ild. ANN. STat. c. 73, §§ 613-15 (Smith-Hurd 1940) ; Parterson, ThE INSURANCE COMMISSIONER IN THE UNITED STATES (1927).

197. Ill. Ann. Stat. c. 73, § 755 (Smith-Hurd 1940) ; id. \$§ 761, 1065.1-.2, 1065.4 (Smith-Hurd Supp. 1957).

198. Id. § 976 (Smith-Hurd 1940); id. §§ 761, 767.1, 1065.16 (Smith-Hurd Supp. 1957). 
state antitrust legislation specifically refers to insurers. ${ }^{199}$ Many courts simply apply antitrust statutes to insurance companies without even referring to the existence of the regulatory legislation..$^{200}$

A few decisions have taken account of the special status of the insurance industry. In Illinois, People v. Aachen \& Munich Fire Ins. $C o .{ }^{201}$ sustained the validity of a bill to enjoin price-fixing by insurance companies. The defendants argued that insurance was not a public utility and hence that the common law against conspiracies and restraint of trade did not apply to them. ${ }^{202}$ The court enjoined the conspiracy, however, reasoning that insurance was a business "affected with the public interest." A contrary result was reached in Texas in Queen Ins. Co. v. State ${ }^{203}$ on the grounds that insurance was not a business affected with a public interest. The matter was more fully considered in a Mississippi case ${ }^{204}$ which held state antitrust statutes to apply to fire insurance companies despite the existence of legislation creating the office of insurance commissioner and vesting him with regulatory powers. Defendant companies had pleaded that the state commissioner knew their rates were uniform and that they all employed a rating bureau to arrive at their prices. They further alleged that the commissioner had approved the uniform rates. ${ }^{205}$ The defendants admitted the insurance commissioner could initiate proceedings but, on a theory of primary jurisdiction, denied that the plaintiff could do so. ${ }^{208}$ The court nevertheless sustained the action, finding no relation between the insurance and antitrust laws. ${ }^{207}$

199. WPA, State Anti-Trust Laws Lv (Martin ed. 1940); see also Griffin v. Palatine Ins. Co., 238 S.W. 637 (Tex. Comm'n of App. 1922).

200. Hartford Fire Ins. Co. v. State, 76 Ark, 303, 89 S.W. 42 (1905); Atlanta Ass'n of Fire Ins. Agents v. McDonald, $181 \mathrm{Ga}$ 105, 181 S.E. 822 (1935); Beechley v. Mulville, 102 Iowa 602,70 N.W. 107, rehearing denied, 71 N.W. 428 (1897); State v. Phipps, 50 Kan. 609, 31 Pac. 1097 (1893); Aetna Ins. Co. v. Commonwealth, $106 \mathrm{Ky}$. 864, 51 S.W. 624 (1899); Huston v. Reutlinger, 91 Ky. 333, 15 S.W. 867 (1891); Hartford Fire Ins. Co. v. Raymond, 70 Mich. 485, 38 N.W. 474 (1888); Miller v. Fidelity Union Fire Ins. Co., 126 Miss. 301, 88 So. 711 (1921); American Fire Ins. Co. v. State, 75 Miss. 24, 22 So. 99, 103 (1897); State ex rel. Crow v. Firemen's Fund Ins. Co., 152 Mo. 1, 52 S.W. 595 (1899); State v. Surety Co., 91 Neb. 22, 135 N.W. 365 (1912); McCarter v. Firemen's Co., 74 N.J. Eq. 372, 73 Atl. 80 (Ct. Err. \& App. 1909); Harris v. Commonwealth, 113 Va. 746, 73 S.E. 561 (1912).

201. 126 Ill. App. 636 (1906).

202. Id. at 641 .

203. 86 Tex. 250, 24 S.W. 397 (1893).

204. Aetna Ins. Co. v. Robertson, 126 Miss. 387, 88 So. 883 (1921).

205. Id. at 396,88 So. at 887.

206. Id. at $400-01,88$ So. at 888 .

207. Id. at $403-04,88 \mathrm{So}$, at 889 . Among the decisions looking in the same general direction are Agricultural Ins. Co. v. Aetna Ins. Co., 119 Kan. 452, 239 Pac. 974 (1925); State $e x$ rel. Barker v. Assurance Co., 251 Mo. 278, 158 S.W. 640 (1913) ; Potomac Fire Ins. Co. v. State, 18 S.W.2d 929 (Tex. Civ. App. 1929). Cf. Opinion of the Justices, 271 Mass. 582, 171 N.E. 294 (1930) in which the court held it would be unconstitutional to create a state auto insurance company to which all motorists would be required to pay premiums, because it would constitute a monopoly and only regulated public utilities should be permitted that sheltered status. 
The only case found squarely opposed is Board of Ins. Comm'rs $v$. Sproles Motor Freight Lines, ${ }^{208}$ in which the Texas court considered the validity of a statute permitting the Board of Insurance Commissioners to fix insurance rates for motor carriers. It was argued that the statute was in conflict with specific antitrust statutes dealing with the insurance business. The court held that an insurer quoting rates fixed by the state administration did not violate the state antitrust statute thereby. ${ }^{209}$ The implication, of course, is that the existence of regulation constitutes a pro tanto exemption from antitrust legislation.

Such was the state of the law prior to 1944 . In that year the Supreme Court in United States v. South-Eastern Underwiters $A s s^{\prime} n{ }^{210}$ overturned precedents almost a century old by holding that insurance constituted "commerce" and hence was subject to regulation by federal legislation. It followed that the antitrust laws could be applied to various aspects of the business. The Court rejected the argument that Congress could not have intended the antitrust laws to apply to insurance because it must have been aware of the state regulation already existing in $1890 .{ }^{211}$ It also brushed aside the argument that holding insurance subject to the Sherman Act would destroy state regulation:

"The argument that the Sherman Act did necessarily invalidate many state laws regulating insurance we regard as exaggerated. A few states go so far as to permit private insurance companies, without state supervision, to agree upon and fix uniform insurance rates. . . . No states authorize combinations of insurance companies to coerce, intimidate, and boycott competitors and consumers in the manner here alleged, and it cannot be that any companies have acquired a vested right to engage in such destructive business practices." 212

Mr. Chief Justice Stone delivered a vigorous dissenting opinion in which he said that the decision substituted for the varied and detailed state regulation developed over a period of years the limited aim and indefinite command of the Sherman Act for the suppression of restraints on competition in the marketing of goods and services affecting interstate commerce, to be applied by the courts to the insurance business as best they might. ${ }^{213}$

208. 94 S.W.2d 769 (Tex. Civ. App. 1936).

209. Id. at 773 .

210. 322 U.S. 533 (1944).

211. Id. at 559 .

212. Id. at 562 .

213. Id. at 581. 
The insurance companies met this catastrophe by seeking legislative relief. They procured the passage of the McCarran Act of March 9th, 1945, ${ }^{214}$ the essence of which was that after June 30th, 1948 the antitrust laws should be applicable to the business of insurance only to the extent that such business is not regulated by a state law. ${ }^{215}$ The act was designed to assure that existing state power to regulate insurance would continue, and accordingly contained a broad declaration of congressional policy in favor of continued state regulation of insurance in the public interest; congressional silence is not to be construed to impose any barrier to continued state regulation. ${ }^{216} \mathrm{Im}-$ mediately thereafter, the states commenced enacting additional legislation to make sure that they would "regulate" the insurance companies sufficiently to make the McCarran Act operative and thus relieve insurers from the burdens of antitrust legislation. ${ }^{217}$ The McCarran statute itself did not indicate to what degree the states were required to regulate and there has therefore been some variation in the response of the state legislatures. All forty-eight states regulate rates; some twenty-six states have enacted unfair trade practice acts specifically applicable to the insurance business and about ten states have enacted measures with respect to interlocking directorates, acquisition of stock in competitive concerns and the like. ${ }^{218}$ Massachusetts has a statute which contains prohibitions of the type found in the federal antitrust statutes. In addition, it has a catch-all prohibition against unfair and deceptive practices somewhat comparable to section five of the Federal Trade Commission Act. ${ }^{219}$ This legislation was held adequate to call the McCarran Act into play and to exempt insurers from the operation of the Sherman Act in Miley v. John Hancock Mut. Life Ins. Co. ${ }^{220}$ On the other hand, the Federal Trade Commission in American Hospital \& Life Ins. Co. v. FTC, has taken the position that the existence of state legislation merely makes state and federal jurisdiction over the insurance companies concurrent in character. ${ }^{221}$ Other litiga-

214. 59 STAT. 33 (1945), 15 U.S.C. \$\$ 1011-14 (1952).

215. 59 Stтr. 33 (1945), 15 U.S.C. § 1012 (1952).

216. Wilburn Boat Co. v. Fireman's Fund Ins. Co., 348 U.S. 310, 319 (1955).

217. See Stelzer, The Insuraince Industry and the Antitrust Laws, 1955 INs. L.J. 137; Donovan, State Regulation of Insurance, 1956 INs. L.J. 11; Donovan, Regulation of Insurance Under the McCarran Act, 15 LAw \& ConTEMP. PRoB. 473, 485-88 (1950).

218. Naujoks, Eight Years After S.E.A.U., 35 Marg. L. REv. 339, 351, 354-55 (1952); Brook, Public Interest and the Commissioners-All Industry Laws, 15 LAw \& Contemp. PROB. 606, 611 (1950).

219. 38 STAT. 719 (1914), as amended, 15 U.S.C. § 45 (1) (1952).

220. 148 F. Supp. 299, 302 (D. Mass.), aff'd, 242 F.2d 758 (1st Cir. 1957).

221. This position was reversed by the circuit court. 243 F.2d 719 (5th Cir. 1957), cert. granted, 26 U.S.L. WEEK 3145 (U.S. Nov. 12, 1957) (No. 436). 
tion instituted by the Commission and private parties is pending in various courts at the present time. That some aspects of the insurance business are subject to antitrust scrutiny despite state regulation of a general nature is demonstrated by recent decisions. ${ }^{222}$

\section{BANKING}

Financial institutions are supervised both by the federal and state governments. It is not unusual for state statutes to provide separately for the organization, capitalization and powers of banking corporations. ${ }^{223}$ Perhaps the most significant feature of that legislation is the power vested in a state officer to make regular examinations of banks and to take action if he finds unsound conditions to exist. In Illinois that officer is the Director of Financial Institutions, who is directed to make periodic examinations. ${ }^{224}$ If he finds the bank's capital has been depleted or the business is being conducted in an unsafe manner, he may take possession of the bank and operate it or throw it into receivership. ${ }^{225}$ Lending limits are spelled out and the withdrawal of capital is prohibited in circumstances which might imperil the safety of depositors. ${ }^{228}$

At the federal level jurisdiction over banks is vested in several governmental departments. The Comptroller of the Currency has extensive powers under the National Bank Act.227 Under the Federal Reserve Act ${ }^{228}$ the Board of Governors of the Federal Reserve System exercises sweeping powers over member banks, both state and federal. Finally, the Federal Deposit Insurance Corporation enjoys jurisdiction over banks whose deposits are insured by that agency. Under the National Bank Act, the rate of interest which a bank may charge is limited by a complex formula depending on local usury statutes, the rediscount rate and other factors. ${ }^{229}$ The Board of Governors may also regulate the rate of interest to be paid by member banks to time and savings depositors. ${ }^{230}$ Federal agencies also have extensive powers with respect to such items as examinations and loan limits, and even

222. United States v. New Orleans Ins. Exchange, 148 F. Supp. 915 (E.D. La. 1957); United States v. Insurance Bd., 144 F. Supp. 684 (N.D. Ohio 1956). See Note, 105 U. PA. L. REV. 977 (1957).

223. E.g., Ill. ANN. Stat. c. 16ז/2, §§ 101-03 (Smith-Hurd Supp. 1957).

224. $I d . \S 148$.

225. Id. $\S \S 151-53$.

226. Id. \$§ 132-34, 141-42, 151-52.

227. 38 StaT. 261 (1913), as amended, 12 U.S.C. \$\$ 1-3 (1952).

228. 38 STAT. 251 (1913), as amended, 12 U.S.C. $\$ \$ 221-23$ (1952).

229. 48 STAT. 191 (1933), as amended, 12 U.S.C. $\$ 85$ (1952).

230. 48 STAT. 182 (1933), as amended, 12 U.S.C. $\$ 371 \mathrm{~b}$ (1952). 
have power to change bank management, which they have sometimes exercised. ${ }^{231}$ Indeed the chairman of the Federal Deposit Insurance Corporation testified: "Banking is the most carefully and closely supervised and regulated industry in the United States." 232

Surprisingly few reported cases deal with the application to banks of the antitrust laws and related common-law rules. In two cases the courts talked as if banks were subject to antitrust principles but held that the action would not lie on other grounds. ${ }^{293}$ In Hall $v$. San Jacinto Bank, ${ }^{234}$ the Texas court said, but did not hold, that an agreement between two banks to stifle competition with respect to payment of interest on the deposit of county funds was against public policy and void. Application of the Clayton Act to banking was discussed in Transamerica Corp. v. Board of Governors, ${ }^{235}$ wherein the corporation argued that Congress had not in the past regulated the banking business by general corporate legislation, but rather by special banking legislation, and that Congress had dealt specifically with banks under the currency powers because of the doctrine that banking was not commerce. Hence, the argument ran, Congress did not contemplate application to banking in enacting the Clayton Act. The court, however, said that since Congress intended to exercise all its powers under the commerce clause banks were subject to the statute, ${ }^{236}$ but held that there was a failure of proof. The federal Attorney General takes the position that approval by the Comptroller of the Currency is no bar to an action against a bank merger under the provisions of the Clayton Act. ${ }^{237}$ On the other hand, he has admitted that:

231. Hearings Before the Subcommittee on the Study of Corporate Mergers, of the Senate Committee on the Judiciary, 84th Cong., 2d Sess. 41 (1956).

232. Id. at 90. Two provisions of the federal antitrust laws should be noted with respect to banks. In the first place, $\$ 7$ of the Clayton Act, 38 STAт. 731 (1914), as amended, 15 U.S.C. $\$ 18$ (1952), probably inadvertently, is largely ineffective with respect to mergers and consolidations of banks because by its terms it only prohibits such mergers when accomplished through the purchase of stock. Since banks normally are not permitted under banking statutes to purchase stock in any corporation, they are unlikely to employ that method of merger and the language of the statute does not reach other types of acquisitions. Note also that $\S 8$ of the Clayton Act, id. $\S 19$, prohibiting directorships in competing corporations is to be enforced by the Board of Governors of the Federal Reserve System and not by the Federal Trade Commission insofar as banks are concerned. Indeed, the statute spells out special rules with respect to common directorships among the banks.

233. United States v. Chicago Mortgage Bankers Ass'n, 123 F. Supp. 251 (N.D. I11. 1954) ; Peoples Bank v. Lamar County Bank, 107 Mrss. 852, 66 So. 219 (1914), rev'd on rehearing, 67 So. 961 (1915).

234. 255 S.W. 506 (Tex. Civ. App. 1923).

235. 206 F.2d 163 (3d Cir.), cert. denied, 346 U.S. 901 (1953).

236. Id. at $165-66$.

237. 38 SrAT. 731 (1914), as amended, 15 U.S.C. $\$ 18$ (1952). See Gruis, Antitrust Laws and Their Application to Banking, 24 GEO. WASH. L. REV. 89, 101 (1955). 
"Broad, general statutes, such as the antitrust laws, are not always easily reconcilable with highly specialized federal and state banking laws and the policy which underlies them. . . . Admittedly a high degree of uniformity and cooperation between banks is essential both for security and to provide the services depositors require from their banks." 238

It was also said that agreements among bankers with respect to the handling of checks and the like are not likely to be objectionable under the Sherman Act. ${ }^{239}$

\section{AlCOHOLIC BeVERAgES}

As in the case of banking, control over intoxicants is divided between the federal government and the states. Most states have stringent measures controlling the traffic in such commodities. ${ }^{240}$ The Illinois statute starts out by a sweeping prohibition against any dealing in liquor except as permitted by the statute. ${ }^{241}$ A commission is created to grant licenses, adopt regulations and the like. ${ }^{242}$ Licenses are to be issued to manufacturers who may only make sales to distributors and importing distributors, the effect being to compel distribution of the goods through a middle man. ${ }^{243}$ Beer, however, may be sold directly to retailers by brewers. ${ }^{244}$ Neither a distiller nor other manufacturer may be issued a license as a distributor or importing distributor and the prohibition runs against officers, shareholders and the like as well as the licensee itself. ${ }^{245}$ No manufacturer may be issued a retailer's license (with minor exceptions) and no retail licensee may be engaged in the trade as a manufacturer or distributor. ${ }^{248}$ There follow prohibitions upon the extension of credit by manufacturers or distributors to retailers designed to correct the evils of the "tied house" of pre-prohibition days. Thus it is unlawful for the retailer to accept or receive credit beyond the normal period (thirty days) and

238. Id. at $90,93$.

239. Id. at 94. Cf. Matter of Patterson, 18 Hun 221, 223 (N.Y. Sup. Ct. 1879), aff'd per curiam, 78 N.Y. 608 (1879). Berle, Banking Under the Anti-Trust Laws, 49 Colum. L. REv. 589 (1949). At this writing there is pending in the Congress a bill which would tighten the banking laws with respect to mergers but would leave authority over such mergers in the banking supervisory agencies rather than in the federal Attorney General or the Federal Trade Commission. AMERICAN ENTERPRISE Ass'n, ANALYsis of Financial Institurions ACT of 1957, at 6, 9-10 (1957).

240. E.g., ILl. Ann. STaT. c 43, §§ 94-196 (Smith-Hurd 1944).

241. Id. § 96.

242. $I d . \S 108$.

243. Id. $\$ 115$ (a).

244. Id. $\$ 115$ (d).

245. Id. $\S 121(\mathrm{a})$.

246. $I d . \S 121(\mathrm{e})$. 
it is unlawful for the manufacturer or distributor to give the retailer anything of value, the statute setting out those prohibitions in great detail.247 No manufacturer or distributor may furnish equipment to a retailer, pay for his license, lend him money or have an interest in his business. ${ }^{248}$ Furthermore, the manufacturer or distributor is not to provide interior decorations, signs or other facilities except as limited by detailed prescriptions in the statute. A sign, for example, may be given to the retailer provided it does not cost more than $\$ 125.00 .^{249}$ Legislation in other states contains significantly different provisions, but in the main is equally comprehensive.

Founded upon the twenty-first amendment, federal controls are exercised under the Federal Alcohol Administration Act. ${ }^{250}$ That statute likewise requires licensing of all activities in connection with alcoholic beverages. One who is to engage in the importing, distilling or brewing of liquors or the sale thereof in interstate commerce must secure a federal permit. ${ }^{251}$ The balance of the statute consists of prohibitions bearing a resemblance to the antitrust laws. Thus it is made unlawful to enter into an agreement whereby the retailer shall purchase his requirements of liquors from one manufacturer or wholesaler. ${ }^{252}$ There follow detailed prohibitions with respect to inducements which might have the effect of requirements contracts. Thus it is unlawful for the manufacturer or wholesaler to acquire an interest in the retailer's license or in his real or personal property used in the business or to furnish equipment and the like. The manufacturer and the wholesaler are also prohibited from paying the retailer for advertising services, guaranteeing his loaris, extending credit beyond usual periods, or requiring the retailer to dispose of a quota of liquor. ${ }^{253}$ It is unlawful for the wholesaler or distiller to make sales upon consignment. ${ }^{254}$ Accurate labeling is required ${ }^{255}$ and advertising must be non-deceptive in character and specific in terms. ${ }^{256}$ Finally, interlocking directorates among those engaged in the manufacture of alcoholic beverages are forbidden absent approval of the Secretary of the Treasury. ${ }^{257}$

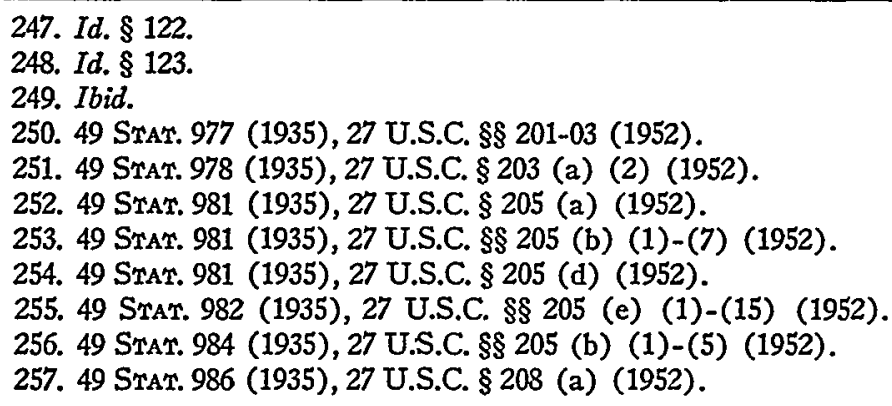


Prior to adoption of the eighteenth amendment, the business of manufacturing and distributing alcoholic beverages was fully subject to antitrust laws and the common-law rules against restraints of trade. Thus in a Nebraska case ${ }^{258}$ the court held a combination to monopolize the distilling business invalid at common law in quo warranto proceedings.

Since adoption of the twenty-first amendment, there has been a series of interesting cases with respect to the application of the antitrust laws to the liquor trade. The first decision was Washington Brewers Institute v. United States, ${ }^{259}$ in which the brewers were indicted for combining to fix prices. Defendants pleaded a state liquor statute requiring the posting of prices by each brewer in specific zones and forbidding changes in prices without a time interval of a period of days. It was held that the Sherman Act was still applicable:

". . [ [T] he broad theory of the Sherman Act that trade should be free of artificial restraints is in many respects incompatible with the policy of state liquor-control legislation; and wherever such conflicts exist the Sherman Act must give way, just as the commerce clause itself gives way in identical circumstances. . . . But we should be slow to assume that these states have undertaken to sanction combinations among producers having as their purpose the fixing of uniform and artificial beer prices. . . . The state laws regulatory of the traffic in malt liquors are directed toward individual conduct. Obedience to them is not rendered difficult or impracticable by the enforcement of a federal statute declaring price-fixing combinations unlawful. In arriving at prices to be charged for their commodity brewers are not required by the states to act otherwise than as free agents, nor are they expected to confederate together with the design of suppressing legitimate competition in respect of either quality or price." 260

The next case, United States $v$. Frankfort Distilleries, Inc., ${ }^{261}$ involved an indictment against Colorado liquor dealers alleging a conspiracy to fix prices at "fair trade" levels. The indictment was sustained : the Supreme Court said that the twenty-first amendment had not given the states exclusive power to regulate the intrastate liquor business and that no conflict was presented between the federal antitrust laws and state liquor control legislation. ${ }^{262}$

258. State v. Nebraska Distilling Co., 29 Neb. 700, 46 N.W. 155 (1890). Accord, Dittman v. Distilling Co., 64 N.J. Eq. 537, 54 Atl. 570 (Ch. 1903); Brooklyn Distilling Co. v. Standard Distilling and Distributing Co., 193 N.Y. 551, 86 N.E. 564 (1908); Nestor v. Continental Brewing Co., $161 \mathrm{~Pa} .473,29$ At1. 102 (1894).

259. 137 F.2d 964 (9th Cir.), cert. denied, 320 U.S. 776 (1943).

260. Id. at 968.

261. 324 U.S. 293 (1945).

262. Id. at 299. 
The converse issue was then considered by the Maryland court in Dundalk Liquor Co. v. Tarves. ${ }^{263}$ A Maryland statute directed administrative officers to fix maximum discounts in the sale of liquor to retailers and to require the filing of price schedules proposing changes. The statute was held valid against an argument that it interfered with federal power exercised under the commerce clause in the form of the Sherman Act. In the opinion it was said:

"We assume, without deciding, that the requirements of schedules of price changes and notice to competitors tend to restrict competition and maintain prices and that such conduct by individuals, under no compulsion by law, would violate the Sherman Act." 264

Maryland law was again considered in United States $v$. Maryland State Licensed Beverage Ass'n, ${ }^{265}$ which dealt with the conflict between the Sherman Act and a state statute permitting administrative officers to regulate price changes by requiring notice of prices and prohibiting discrimination. The state officers did not have power directly to fix prices. A motion to dismiss the indictment was denied; the court said that it would wait to see what it thought of the situation when the evidence had been adduced: $:^{268}$

"The Maryland law and the Sherman Act come into direct conflict at certain points. The Maryland statute requires that schedules of price changes be filed and that notice thereof be given to competitors. Such action apart from the State statute would be forbidden by the Sherman Act. . . . If the indictment went no further than this, it could not stand. But it does go further, and charges conduct beyond anything reasonably within the ambit of the State policy." 267

To date, therefore, the courts have not held the liquor trade exempt from the antitrust laws by reason of the existence of state and federal regulation. They have, however, indicated that there is at least a potential conflict between the two types of statutes and that state statutes of a price-fixing type would in some instances render antitrust legislation inapplicable. ${ }^{288}$

263. 201 Md. 58, 92 A.2d 560 (1953).

264. Id. at $68,92 \mathrm{~A} .2 \mathrm{~d}$ at 564 .

265. 138 F. Supp. 685 (D. Md. 1956).

266. Id. at 703 .

267. Id. at 701. Cf. United States v. United Liquors Corp., 352 U.S. 991 (1956).

268. See United States v. Maryland State Licensed Beverage Ass'n, 138 F. Supp. 685, 699 (D. Md. 1956). 


\section{OTHER INDUSTRIES}

Agriculture, once the freest of all occupations, is now heavily regulated. ${ }^{269}$ Certain agricultural activities are provided broad exemptions from the antitrust laws. Producers' cooperatives, for example, are afforded exemptions ${ }^{270}$ under section 6 of the Clayton Act, ${ }^{271}$ section 5 of the Cooperative Marketing Act ${ }^{272}$ and sections 1 and 2 of the Capper-Volstead Act. ${ }^{273}$ The tendency of the courts has been to construe specific exemptions strictly and not to find others by implication. ${ }^{274}$

Express companies, ${ }^{275}$ investment bankers, ${ }^{276}$ operators of bridges $^{277}$ and pipelines, ${ }^{278}$ and sleeping car proprietors ${ }^{279}$ have all been subjected to extensive regulation, too. An early case held express companies subject to the common-law rules against restraints of trade. ${ }^{280}$ When an agreement has been expressly approved by the ICC, however, the courts will refuse to make it the basis of an action under the antitrust laws. ${ }^{281}$ Likewise, in view of federal regulation, one court has said that the Sherman Act is not fully applicable to the flotation of investment securities. ${ }^{282}$ The opinion, however, went off on the grounds that the syndicate conduct involved did not amount to a conspiracy, but constituted a joint venture for a temporary purpose.

Controversy with regard to the exclusive character of franchises to erect and operate bridges goes back to the famous decision in

269. See, e.g., the Agricultural Adjustment Act of 1938, 52 Srar. 31, 7 U.S.C. $\S \S 1281-83$ (1952); Packers \& Stockyards Act, 42 STAT. 159 (1921), 7 U.S.C. $\$ \S$ 181-83 (1952); Sugar Act of 1948, 61 STAT. 922, 7 U.S.C. $\$ \$ 1100-01$ (1952).

270. See Recent Case, 105 U. PA. L. REv. 996 (1957).

271. 38 STAT. 731 (1914), 15 U.S.C. $\$ 17$ (1952).

272. 44 STAT. 802 (1926), 7 U.S.C. \$\$ $451-57$ (1952).

273. 42 STAT. 388 (1922), 7 U.S.C. \$\$ 291, 292 (1952).

274. See, e.g., United States v. Borden Co., 308 U.S. 188 (1939); Producers' Livestock Marketing Ass'n v. United States, 241 F.2d 192 (10th Cir. 1957), cert. granted, 23 U.S.L. WEEK 3019 (U.S. July 23, 1957) (No. 118); Morrison v. Bandt, 145 Kan. 942, 67 P.2d 584 (1937). But see United States v. Maryland Cooperative Milk Producers, Inc., 145 F. Supp. 151 (D.D.C. 1956); United States v. Dairy Cooperative Ass'n, 49 F. Supp. 475 (D. Ore. 1943); United States v. Swift \& Co., 46 F. Supp. 848, 850 (D. Colo. 1942), remanded on other grounds, 318 U.S. 442 (1943); Dairymen's League v. Weckerle, 160 Misc. 866, 291 N.Y. Supp. 704, 715 (Sup. Ct. 1936).

275. See, e.g., Interstate Commerce Act, 24 STAr. 379 (1887), as amended, 49 U.S.C. $\$ 1$ (1952); IIL. ANN. STAT. c. $1112 / 3$, \$\& 1-3 (Smith-Hurd 1954).

276. See, e.g., Securities Act of 1933, 48 STAT. 74, 15 U.S.C. $\$ 77$ (1952) ; Securities Exchange Act of 1934, 48 STAT. 881, 15 U.S.C. $\$ 78$ (1952); ILL. ANN. STAT. c. $121 \mathrm{I} / 2, \& 137$ (Smith-Hurd 1954).

277. See General Bridge Act of 1946, 60 STAT. 847, 33 U.S.C. \$\$ 525-27 (1952). 278. See, e.g., Interstate Commerce Act \& 1, 24 SrAT. 379 (1887), as amended, 49 U.S.C. \$ I (1952); ILL. ANn. STat c. 111 2/3, \$\$ 1-3 (Smith-Hurd 1954); Pipe Line Cases, 234 U.S. 548 (1914).

279. See, e.g., Interstate Commerce Act $\$ 1,24$ STAT. 379 (1887), as amended, 49 U.S.C. \$1 (1952); ILL ANN. STAT. c. $1112 / 3$, $\$ 1-3$ (Smith-Hurd 1954). 117 U.S. 1, 24 (1886). Railroad Co., 24 Pa. 378, 382 (1855). But cf Express Cases, 1951).

281. United States v. Railway Express Agency, 101 F. Supp. 1008, 1012 (D. Del. 282. United States v. Morgan, 118 F. Supp. 621, $691-93$ (S.D.N.Y. 1953). 
Proprietors of the Charles River Bridge v. Proprietors of the Warren $B$ ridge. ${ }^{283}$ It does not appear, however, that litigation has developed with respect to the application of the antitrust laws to bridge companies.

Courts have held operators of pipelines fully subject to both common-law rules against restraints of trade and to antitrust statutes. ${ }^{284}$ And the same result has been reached in the case of sleeping car proprietors. In the only recent case carefully considering the matter, the court held that ICC regulation of the Pullman Company was restricted to the company's relations with the traveling public and did not control the supply of sleeping car service to the railways. ${ }^{285}$

\section{ConcLusions}

The foregoing survey makes it abundantly plain that the law is in a state of chaos. Some regulated industries are subject to antitrust legislation; others are not. Some courts hold business subject to interventionist enactments to be free from rules prohibiting restraints of trade; others do not. New cases are decided without reference to old precedents and the courts in general have been unable to explain coherently the conclusions they have reached.

No doubt, elementary analysis would clarify the picture. We could, for example, separate the decisions on a basis of jurisdiction so that all the cases decided in one state were grouped together. Perhaps such a breakdown would reveal greater consistency of judicial thinking. In addition, a good many decisions have been compelled by specific statutory language, recognition of which would somewhat clarify the law. Note also the possibility that some states may apply antitrust principles only to necessities and not luxuries, ${ }^{286}$ with oblique results for regulated industries. Finally, and most importantly, a chronological arrangement of the authorities would no doubt be illuminating. At one time the antitrust laws were relied upon to protect the public from all types of monopolies. As the years went by and regulatory commissions were created to control specific industries,

283. 36 U.S. (11 Peters) *420 (1837). It continues to the present day. See, e.g., Talbot v. Louisiana Highway Comm'n, $159 \mathrm{La}$. 910,106 So. 377 (1925). Cf. Nicomen Boom Co. v. North Shore Boom Co., 40 Wash. 315, 82 Pac. 412 (1905).

284. See, e.g., McClellan v. Montana-Dakota Util. Co., 95 F. Supp. 977 (D. Minn. 1951) ; Calor Oil Co. v. Franzell, $128 \mathrm{Ky} .715,109$ S.W. 328 (1908); West Virginia Transp. Co. v. Ohio River Pipe Line Co., 22 W. Va. 600 (1883). Cf. Panhandle Eastern Pipeline Co. v. FPC, 169 F.2d 881, $883-84$ (D.C. Cir.), cert. denied, 335 U.S. 854 (1948).

285. United States v. Pullman Co., 50 F. Supp. 123 (E.D. Pa. 1943). Cf. Keith Ry. Equipment Co. v. Ass'n of American Railroads, 64 F. Supp. 917 (N.D. Ill. 1946). But cf. Chicago, St. Louis \& New Orleans R.R. v. Pullman So. Car Co., 139 U.S. 79, 89 (1891).

286. E.g., Hale \& Hare, Marker Power $§ 3.11$ (1958). 
there has been a tendency to let antitrust principles play a subordinated role in many situations. ${ }^{287}$

It does not appear likely, however, that the foregoing procedures would alone reduce chaos to coherence. Take, for example, Georgia v. Pennsylvania R.R., ${ }^{288}$ decided after the Interstate Commerce Act, as frequently amended, had been in effect for decades. The Interstate Commerce Commission was invested with sweeping powers over the railroads. The Court was not troubled by specific constitutional or statutory provisions. Yet four of the Justices could not agree with five of their brethren as to whether the Sherman Act should be applied to a railroad enterprise. By the vote of a single Justice, the carriers were - held subject to antitrust legislation in addition to the interventionist statutes administered by the Commerce Commission. ${ }^{289}$

A thorough effort to resolve the conflict requires action in several stages. First, the antitrust statutes in question should be analyzed in detail to determine their objectives: the Sherman Act is generally considered an instrument designed to promote competition. The Clayton Act, however, goes at least part of the way toward the regulation of monopoly. Note, for example, that many regulatory commissions are specifically directed by their organic statutes to eliminate price discrimination and that a section of the Clayton Act ${ }^{280}$ is directed to the same end. Under the provisions ${ }^{291}$ of the Clayton Act the regulatory commissions enforce portions ${ }^{292}$ thereof against the various industries under their jurisdiction. We cannot therefore take the Sherman Act as the beginning and end of antitrust legislation; we must take account of the fact that modern antitrust principles go a considerable direction toward "soft" competition.

A second step would involve detailed analysis of the regulatory statutes and administrative action thereunder. Some legislation is not interventionist in character; it merely seeks to promote the public health and safety. Plumbers, for example, may be licensed; ostensibly, at least, the purpose is to protect public health and not to protect plumbers from competition. As we have seen, many of the interventionist statutes

287. Troxar, Economics of Public Utrimiss 190 (1947); Hadley, Public Utilities and the Anti-Trust Lare, 10 B.U.L. REv. 351, 358 (1930); Lake, Competition in the Public Utility Fields, 10 Miss. L.J. 197, $201-03$ (1938); Note, 64 HARV. L. REv. 1154,1156 (1951). Cf. REPORT OF THE ATrORNEY GeNERAL's NaTIONAL CoMMITTEE To STUDY THE ANTITRUST LAwS 270 (1955).

288. Georgia v. Pennsylvania R.R., 324 U.S. 439 (1945).

289. Some observers might deem such a result so burdensome to investors as to amount to a denial of substantive due process of law.

290. 38 STAT. 731 (1914), as amended, 15 U.S.C. $\$ 13$ (1952).

291. 38 Srar. 731 (1914), as amended, 15 U.S.C. \$ 21 (1952).

292. 38 StaT. 731 (1914), as amended, 15 U.S.C. $\S \S 13,14,18,19$ (1952). 
discussed above vary in content. In the broadcasting field entry is rigidly controlled but prices are not fixed. In other areas both prices and entry are controlled while the management of the regulated enterprise remains free to choose methods of production and the like. What is needed is an examination of the degree of monopoly fostered by interventionist controls. In such a study we should have to take account of the competition (particularly inter-industry competition) which remains; putting the question another way, we should have to determine the amount of discretion remaining in management. If the directors of a corporation are so shackled by statutes and administrative action that they have little discretion remaining, it would be odd to require them to enter into competition. For the essence of competition is freedom to make one's own decisions and to move ahead (or backward) at one's own speed. ${ }^{293}$

At the conclusion of such analysis, it should be possible to group interventionist regulation into a number of categories. As suggested above, some commissions fix maximum prices, others fix minimum prices and still others fix all prices; some license entrance into the field and others do not. A few of the statutes appear to empower administrative agencies to enforce policies closely akin to those enunciated in the supplementary antitrust legislation and particularly the Clayton Act.

Finally, a comparison of the multiple antitrust objectives with the specific types of regulation established by analysis would prove suggestive. For each category we could determine roughly the degree of discretion left in business management. We should also have some idea as to whether competition had been eliminated or remained in some sublimated or even active form. It might then be possible to establish criteria for the evaluation of any particular type of public utility control. Examination of the regulatory system in the light of such criteria would then suggest whether specific antitrust principles should be applied to the industry in question.

293. In view of the broad discretion vested in the administrative agencies, any such study would inevitably involve a survey of the actual operation of the regulatory mechanism. 